\title{
Contributions of Glycolipid Biosurfactants and Glycolipid- Modified Materials to Antimicrobial Strategy: A Review
}

\author{
Qin Shu, Hanghang Lou, Tianyu Wei, Xiayu Liu and Qihe Chen *D \\ Department of Food Science and Nutrition, Zhejiang University, Hangzhou 310058, China; \\ 21713041@zju.edu.cn (Q.S.); louhanghang@zju.edu.cn (H.L.); 21913067@zju.edu.cn (T.W.); \\ xiayuliu@zju.edu.cn (X.L.) \\ * Correspondence: chenqh@zju.edu.cn; Tel.: +86-139-6717-1522
}

Citation: Shu, Q.; Lou, H.; Wei, T.; Liu, X.; Chen, Q. Contributions of Glycolipid Biosurfactants and Glycolipid-Modified Materials to Antimicrobial Strategy: A Review. Pharmaceutics 2021, 13, 227. https://doi.org/10.3390/ pharmaceutics 13020227

Academic Editors: Barbara Luppi and Gert Fricker

Received: 24 December 2020

Accepted: 2 February 2021

Published: 6 February 2021

Publisher's Note: MDPI stays neutral with regard to jurisdictional claims in published maps and institutional affiliations.

Copyright: (c) 2021 by the authors. Licensee MDPI, Basel, Switzerland. This article is an open access article distributed under the terms and conditions of the Creative Commons Attribution (CC BY) license (https:// creativecommons.org/licenses/by/ $4.0 /)$.

\begin{abstract}
Glycolipid biosurfactants are natural amphiphiles and have gained particular interest recently in their biodegradability, diversity, and bioactivity. Microbial infection has caused severe morbidity and mortality and threatened public health security worldwide. Glycolipids have played an important role in combating many diseases as therapeutic agents depending on the self-assembly property, the anticancer and anti-inflammatory properties, and the antimicrobial properties, including antibacterial, antifungal, and antiviral effects. Besides, their role has been highlighted as scavengers in impeding the biofilm formation and rupturing mature biofilm, indicating their utility as suitable anti-adhesive coating agents for medical insertional materials leading to a reduction in vast hospital infections. Notably, glycolipids have been widely applied to the synthesis of novel antimicrobial materials due to their excellent amphipathicity, such as nanoparticles and liposomes. Accordingly, this review will provide various antimicrobial applications of glycolipids as functional ingredients in medical therapy.
\end{abstract}

Keywords: glycolipids; nanocomposites; liposomes; antibacterial mechanism; anti-biofilm

\section{Introduction}

Surfactants are a kind of amphiphilic molecules with hydrophilic moieties and hydrophobic moieties and perform excellent interfacial activity between gas, liquid, and solid surfaces. Since their broad range of applications has been put into the food industry, cosmetics, petroleum industry, and sewage treatment, surfactants have become one of the most widely used chemicals in industrial production. However, most chemicallysynthesized surfactants derived from petroleum products, and the massive consumption of petroleum have caused resource exhaustion and environmental pollution. Thus, the exploitation of eco-friendly, biodegradable, and renewable alternative to surfactants has to be settled urgently. In recent years, the emerging of biosurfactants has gained more and more attention, and plenty of expectations have been potentiated due to their versatile functions, such as reducing surface tension, emulsifying activity, and biological properties [1]. Compared to synthetic surfactants, biosurfactants are more popular owing to their higher biodegradability, lower toxicity, thermostability, and tolerance in extreme conditions [2]. The production of biosurfactants is dependent on microbial fermentation of bacteria, fungi, and yeast strains based on low-cost carbon and nitrogen source, even industrial waste and oily byproducts, and the promising and sustainable strategy realizes low energy consumption in a large scale of production. According to their molecular weight, biosurfactants can be segmented into two groups: low molecular weight (LMW) and high molecular weight (HMW), as seen in Figure 1 [3]. Glycolipids [4] and lipopeptides [5] are representative biosurfactants with low molecular weight, such as rhamnolipids [6] and surfactin [7], and the high molecular weight group contains phospholipids [8], lipoprotein [9], and emulsan [8] et al. 


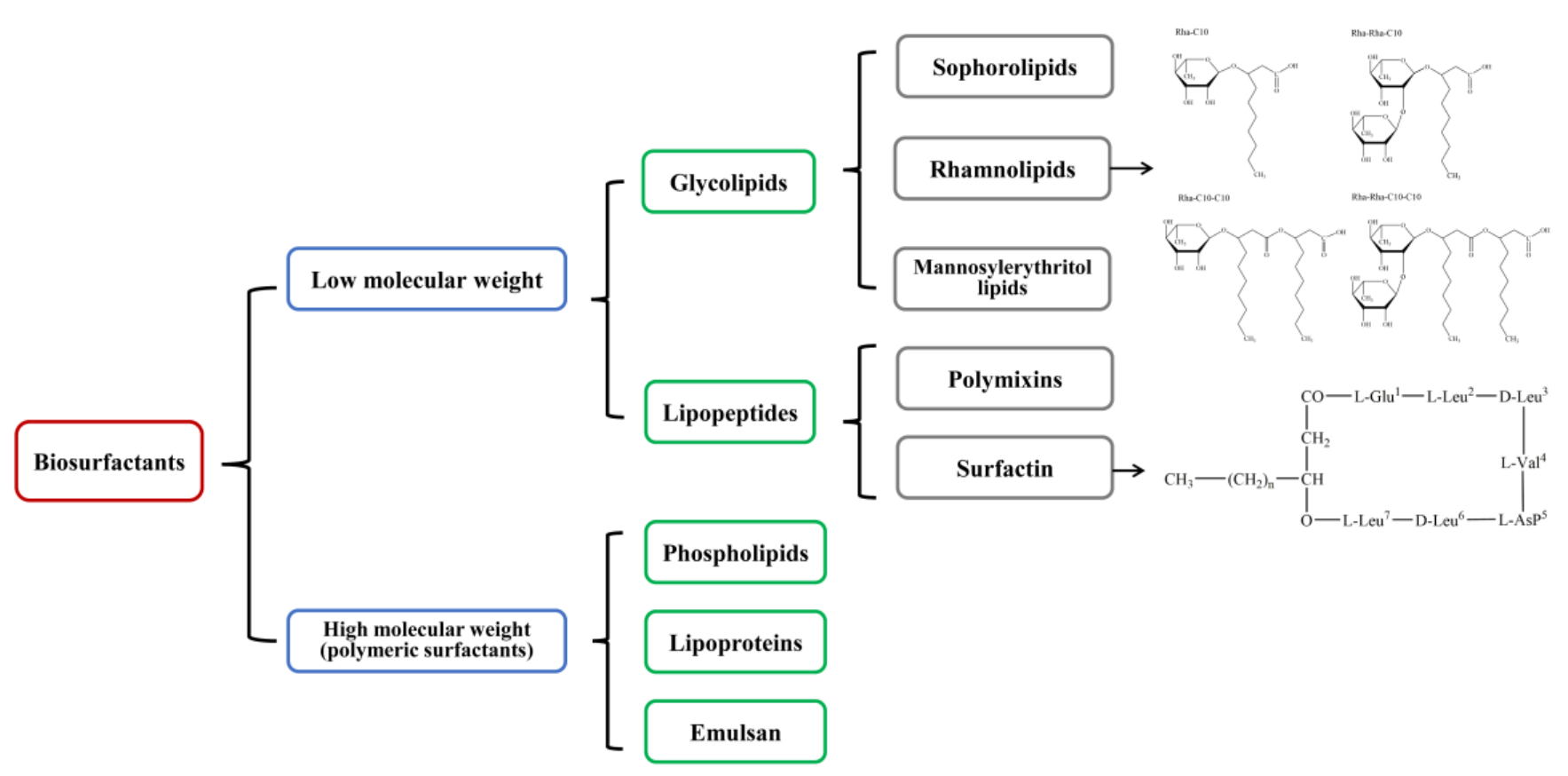

Figure 1. Main groups of biosurfactants.

Glycolipids are one of the most popular biosurfactants with low molecular weight and have been investigated thoroughly and intensively for biotechnological applications. As the name implies, glycolipids comprise two parts: carbohydrate moiety and fatty acid chains linked by a glycosidic bond, which acts as a hydrophilic role and hydrophobic role, respectively. The difference of carbohydrate moiety and fatty acid chains cause the diversity of glycolipids, and the sub-class normally contains rhamnolipids, sophorolipids, mannosylerythritol lipids, cellobiose lipids, trehalolipids, xylolipids, and so on [10]. Except for fundamental characteristics of biosurfactants, most glycolipid-producers are microorganisms isolated from oil-contaminated samples, which implied their potential applications in bioremediation as well as their production on renewable sources. Multiple biological properties have endowed glycolipids with wide potentiality in various fields. According to the literature, glycolipids have been confirmed to show potential anticancer effects and are expected to be efficient candidates for anticancer drugs [5]. For instance, rhamnolipids have shown a significant anticancer effect on human breast cancer cells MCF-7 in a dosedependent manner [11]. Besides, glycolipids exert anti-inflammatory effects on human immune-related diseases as promising immunomodulators. Sophorolipids could modulate the immune response to decrease sepsis-related mortality in animal models, the underlying mechanism involves the reduction of nitric oxide and the regulation of inflammatory cytokines [12]. Remarkably, massive literature reveals that all kind of glycolipids possesses excellent antimicrobial activity against bacteria, fungi, and virus, and the physiological changes induced by glycolipids have been deeply investigated aiming at both planktonic and biofilm state of microorganism [4,6,13-15].

In the previous review [16], abundant work has been devoted to concluding the biotechnological production, functional properties, and potential applications of glycolipid biosurfactants. In this review, a comprehensive intensive study will be carried out directing the contributions of glycolipids and glycolipid-modified materials to antimicrobial therapy.

\section{Glycolipids}

\subsection{Rhamnolipids}

Rhamnolipids (RLs) are one of the glycolipid-type biosurfactants, which are produced mainly by Pseudomonas aeruginosa and most frequently studied due to their effective surface activity and high yields of production [17]. It was firstly reported in 1946 that Bergström et al. discovered an oily glycolipid, named pyolipic acid, was produced by Pseu- 
domonas pyocyanea (P. aeruginosa) after growing on glucose $[18,19]$. Soon after that, Jarvis and Johnson in 1949 have further confirmed the RL isolated from P. aeruginosa contained two $\beta$-hydroxydecanoic acids and two rhamnose moieties, which were linked through a glycosidic bond [20]. Then Edwards and Hayashi have verified the linkage between the two rhamnose moieties is an $\alpha-1,2$-glycosidic linkage in 1965 [21]. Since then, extensive researches have been conducted on RL including broad aspects. So far, P. aeruginosa has been thoroughly investigated as a primary source of RLs with titers over $100 \mathrm{~g} / \mathrm{L}$ [22], and Pseudomonas species are regarded as the main RL producers. Nevertheless, it has been reported that many other non-Pseudomonas isolates can produce RLs as well, leading to the structural diversity of RLs. For instance, there are some studies focused on the production of rhamnolipids by Burkholderia species, which have been shown to produce rhamnolipids that have longer alkyl chains than P. aeruginosa, such as Burkholderia thailandensis [23], Burkholderia plantarii [24], and Burkholderia pseudomallei [25]. Although the diversity of RL-producers has caused variations in the chemical structures of RL, the basic structure was composed of rhamnose moiety and lipid moiety, and the number of rhamnose and the length and number of carbon chain lead to the diversity of RL structure. Generally, there are mainly four types of RL structures produced by Pseudomonas species, including mono-rhamno-mono-lipid (Rha-C10), di-rhamno-mono-lipid (Rha-RhaC10), mono-rhamno-di-lipid (Rha-C10-C10), and di-rhamno-di-lipid (Rha-Rha-C10-C10), as shown in Figure 2.

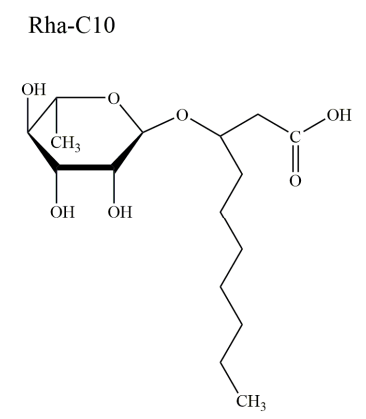

Rha-C10-C10

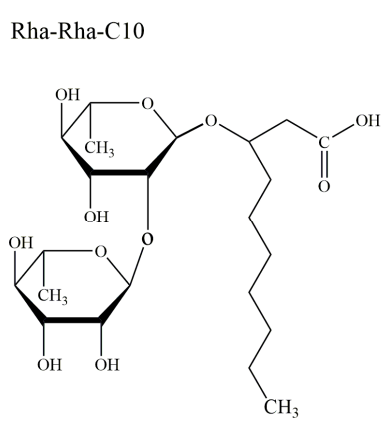

Rha-Rha-C10-C10

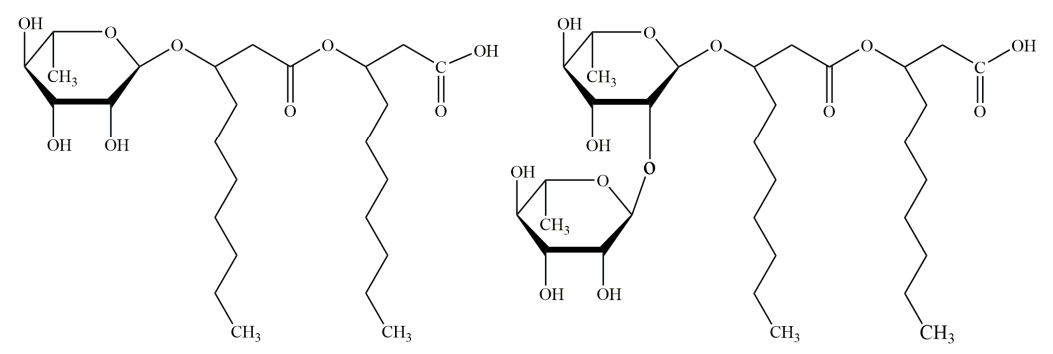

Figure 2. Common structures of rhamnolipids produced by Pseudomonas species.

Earlier in 1971, the antimicrobial spectrum of rhamnolipids has been studied, suggesting the broad-spectrum antimicrobial activity functioned against common microbes including gram-positive and gram-negative bacteria, such as Streptococcus faecalis, Staphylococcus aureus, Bacillus subtilis, and Proteus vulgaris [26]. Whereafter, a large number of intensive and deep researches has been conducted about the microorganism sterilizing actions of rhamnolipids involving planktonic and biofilm cells, as seen in Table 1. As the most important pathogens, Staphylococcus aureus and Staphylococcus epidermidis were reported to be influenced as rhamnolipids have suppressed the growth of planktonic cells at MIC of 0.06 and $0.12 \mathrm{mg} / \mathrm{mL}$, and dispersed pre-formed biofilms up to 93\% [27]. Ferreira et al. provided evidence that gram-positive pathogens Listeria monocytogenes, Bacillus cereus, and S. aureus were more sensitive to rhamnolipids, indicating the sterilizing effects of rhamnolipids were pH-dependent [28]. Summarily, the inducement of bacterial death is 
attributed to cell lysis along with consequent leakage of cellular components, which was already confirmed by visualized proofs such as SEM and TEM pictures. As the target of rhamnolipids to planktonic bacteria, the cell membrane has been altered and damaged with an increase in cell permeability and reduction on cell surface hydrophobicity [28], because the unique amphiphilic character allows the interaction between rhamnolipids and phospholipids [29].

Interestingly, they found that gram-negative Salmonella enterica and E. coli showed resistance to rhamnolipids at all tested concentrations and all $\mathrm{pH}$ levels. Generally speaking, glycolipids have stronger antibacterial effects on gram-positive bacteria than gram-negative bacteria, which may be owing to the difference in cell membrane composition. The cell envelope of gram-negative bacteria consists of the outer membrane (lipopolysaccharides and phospholipids), peptidoglycan, and internal plasma membrane, which is more complex and defensive than gram-positive bacteria. The special structure made it difficult for glycolipids to enter gram-negative bacteria, while there is a common agreement that the underlying mechanism of antibacterial activity involves reducing membrane permeability, loss of intracellular constituents, and cell apoptosis induced by membrane lysis.

Generally speaking, the inducement of bacterial death is attributed to cell lysis along with consequent leakage of cellular components, which was already confirmed by visualized proofs such as SEM and TEM pictures. As the target of rhamnolipids to planktonic bacteria, the cell membrane has been altered and damaged with an increase in cell permeability and reduction on cell surface hydrophobicity [28], because the unique amphiphilic character allows the interaction between rhamnolipids and phospholipids [29].

Biofilm is considered as the sessile community of planktonic microorganism fixed at the solid surface, and plenty of researches have exhibited the anti-biofilm properties of rhamnolipids. Biofilms are an important concern among food processing industries, resulting in contamination of pipelines, corrosion of equipment, and final food spoilage. Araujo et al. discovered the biofilm of P. fluorescens and L. monocytogenes (biofilm-forming bacteria related to foodborne disease) was reduced up to $79 \%$ and $74 \%$ by purified rhamnolipids, respectively, while microbial adhesion was entirely inhibited in the culture medium [30]. Besides, oral health and hygiene have always been threatened by relating oral bacteria, and rhamnolipids were studied to eradicate the bacterial biofilm of oral disease. As one of the major etiological agents in dental caries, the adhesion of Streptococcus mutans on polystyrene surfaces was reduced by rhamnolipids, and its pre-formed biofilm was also disrupted according to Abdollahi et al. [31]. Similarly, Elshikh et al. also found that rhamnolipids from non-pathogenic Burkholderia thailandensis E264 revealed potent abilities to destruct mature biofilm of some oral pathogens (Streptococcus oralis, Actinomyces naeslundii, Neisseria mucosa, and Streptococcus sanguinis), forecasting their prospective oralrelated applications against oral-bacteria biofilms [32]. In conclusion, the biofilm-inhibiting behavior of rhamnolipids was due to blocking the initial adhesion stage. To figure out the specific role of rhamnolipids playing in the biofilm formation process, Kim et al. investigated the physicochemical interactions between rhamnolipids and Pseudomonas aeruginosa biofilm layers [33]. They demonstrated that a decrease in surface free energy on the membrane, interaction with some EPS proteins, and loss of EPS amount were several key factors in rhamnolipid-mediated biofilm reduction.

Furthermore, rhamnolipids also perform excellent inhibiting effects on fungi including not only hyphal growth but also spore germination. For detrimental fungi in the plant, Kim et al. reported that rhamnolipids showed significant antifungal activity against Phytophthora capsici mainly due to a lytic effect on zoospores at a concentration of $10 \mathrm{mg} / \mathrm{mL}$, and also suppressed the germination of zoospores and the growth of hypha [34]. Goswami et al. also confirmed the effectiveness of rhamnolipid in controlling Colletotrichum falcatum in vitro as well as in vivo. Results showed $100 \mathrm{mg} / \mathrm{mL}$ RL-DS9 exhibited 86.6\% inhibition against C. falcatum spore germination, and in the same concentration, RL-R95 showed $83.3 \%$ inhibition. The antifungal mode came from disruption of the fungal membrane and made it possible for its application as an alternative fungicide to control red 
rot disease of sugarcane [35]. On the other hand, rhamnolipids are able to combat those harmful fungi derived from animals or humans. For instance, Sen et al. elucidated that purified rhamnolipid could effectively suppress spore germination and hyphal proliferation of Trichophyton rubrum in mice models at a concentration of $500 \mu \mathrm{g} / \mathrm{mL}$, which can be a promising candidate to cure dermatophytic infections, known as the most prevalent superficial mycoses worldwide [36]. Meanwhile, the biofilm of fungi has always been detrimental to eliminate microbial contamination because of its high resistance and low living demands, yet rhamnolipids have outstanding performance in controlling fungi biofilm. Singh et al. discovered $90 \%$ of pre-formed Candida albicans biofilm on polystyrene surfaces was reduced by rhamnolipids in a dose-dependent manner [37]. Upon yeast type of fungi, the pre-formed biofilm of Yarrowia lipolytica was removed effectively by rhamnolipids at low concentrations, reported by Dusane et al. [38].

Table 1. Antimicrobial effects of rhamnolipids reported to date.

\begin{tabular}{|c|c|c|c|c|}
\hline $\begin{array}{c}\text { Producing } \\
\text { Microorganism }\end{array}$ & Target Microorganism & Microbial Type & Inhibitory Effects & Reference \\
\hline \multirow{2}{*}{$\begin{array}{l}\text { Pseudomonas aeruginosa } \\
\text { PA1 }\end{array}$} & Listeria monocytogenes & Gram-positive & \multirow{2}{*}{ Anti-biofilm effects } & \multirow{2}{*}{ [30] } \\
\hline & Pseudomonas fluorescens & Gram-negative & & \\
\hline \multirow{2}{*}{$\begin{array}{l}\text { Pseudomonas aeruginosa } \\
\text { OBP1 }\end{array}$} & Staphylococcus aureus & Gram-positive & \multirow{2}{*}{ Antibacterial effects } & \multirow{2}{*}{ [27] } \\
\hline & Klebsiella pneumoniae & Gram-negative & & \\
\hline \multirow{4}{*}{ P. aeruginosa DS10-129 } & Staphylococcus epidermidis & \multirow{3}{*}{ Gram-positive } & \multirow{4}{*}{$\begin{array}{l}\text { Anti-biofilm effects by } \\
\text { disrupting the initial } \\
\text { adhesion }\end{array}$} & \multirow{4}{*}[39]{} \\
\hline & $\begin{array}{l}\text { Staphylococcus } \\
\text { aureus }\end{array}$ & & & \\
\hline & $\begin{array}{l}\text { Streptococcus } \\
\text { salivarius }\end{array}$ & & & \\
\hline & Candida tropicalis & Fungi & & \\
\hline Pseudomonas sp. PS-17 & Bacillus subtilis & Gram-positive & Antibacterial effects & {$[40,41]$} \\
\hline \multirow{3}{*}{ - } & Bacillus cereus & Gram-positive & \multirow{3}{*}{$\begin{array}{l}\text { Antibacterial effect } \\
\text { depending on } \mathrm{pH}\end{array}$} & \multirow{3}{*}{ [28] } \\
\hline & Escherichia coli & Gram-negative & & \\
\hline & Salmonella enterica & Gram-negative & & \\
\hline $\begin{array}{l}\text { Pseudomonas aeruginosa } \\
\text { MN1 }\end{array}$ & Streptococcus mutans & Gram-positive & Anti-biofilm effects & {$[31]$} \\
\hline- & Helicobacter pylori & Gram-negative & Anti-biofilm effects & {$[42]$} \\
\hline \multirow{2}{*}{$\begin{array}{l}\text { Pseudomonas aeruginosa } \\
\text { strain B5 }\end{array}$} & Cercospora kikuchii & \multirow{2}{*}{ Fungi } & \multirow{2}{*}{$\begin{array}{l}\text { Inhibiting spore germination } \\
\text { and hyphal growth }\end{array}$} & \multirow{2}{*}{ [34] } \\
\hline & Phytophthora capsici & & & \\
\hline - & Yarrowia lipolytica & Fungi & Anti-biofilm effects & {$[38]$} \\
\hline $\begin{array}{l}\text { Pseudomonas aeruginosa } \\
\text { DSVP20 }\end{array}$ & Candida albicans & Fungi & Anti-biofilm effects & [37] \\
\hline $\begin{array}{l}\text { Pseudomonas aeruginosa } \\
\text { DS9 }\end{array}$ & Colletotrichum falcatum & Fungi & $\begin{array}{l}\text { Inhibiting spore germination } \\
\text { and mycelial growth }\end{array}$ & [35] \\
\hline $\begin{array}{l}\text { Pseudomonas aeruginosa } \\
\text { SS14 }\end{array}$ & Trichophyton rubrum & Fungi & $\begin{array}{l}\text { Inhibiting spore germination } \\
\text { and hyphal proliferation }\end{array}$ & [36] \\
\hline
\end{tabular}

\subsection{Sophorolipids}

Sophorolipids (SLs) are one of the representative glycolipid biosurfactants owing to their homogeneous product in high yield, which has been intensively investigated and commercialized by some companies [43]. The original discovery of sophorolipids was dated back to 1961 when Gorin et al. firstly revealed that an extracellular glycolipid mixture was produced by Torulopsis magnoliae, which was corrected as Candida apicola later 
in 1968 [44]. Simultaneously, Tulloch et al. also found extracellular glycolipids were yielded by Candida bogoriensis in 1968 [45]. In the next decades, sophorolipids have gained extensive interest and have been proved to be synthesized by multiple species of yeast strains like Starmerella bombicola, Candida riodocensis, Candida stellate, and Wickerhamiella domercqiae, growing on carbohydrates and lipophilic substrates with titers over $400 \mathrm{~g} / \mathrm{L}$ [46-48]. Moreover, the diversity of producing species has determined the structure of their metabolic products. Normally, the molecular structure of sophorolipids is composed of a hydrophobic fatty acid tail of 16 or 18 carbon atoms and a hydrophilic carbohydrate head sophorose and can be divided into two main forms: acidic form and lactonic form, as shown in Figure 3. Specifically, a long chain of hydroxyl fatty acid was $\beta$-glycosidically attached to the sophorose moiety, and the carboxylic tail of the fatty acid is either free (acidic form) or esterified at the $6^{\prime}$ - or $6^{\prime \prime}$-position (lactonic form). Furthermore, the variation of the structure is also reflected in the carbon number, unsaturation, and hydroxylation of the fatty acid chain in sophorolipids, depending on different kinds of carbon sources in microbial fermentation [49]. Thus, the structural difference has strongly influenced the biological and physicochemical activities and the degree of lactonization is the key factor. Generally, lactonized sophorolipid shows superior surface activity and antimicrobial effects and exhibits more application potential, which the acidic form demonstrates better forming capacity and solubility [50].

Lactonic form

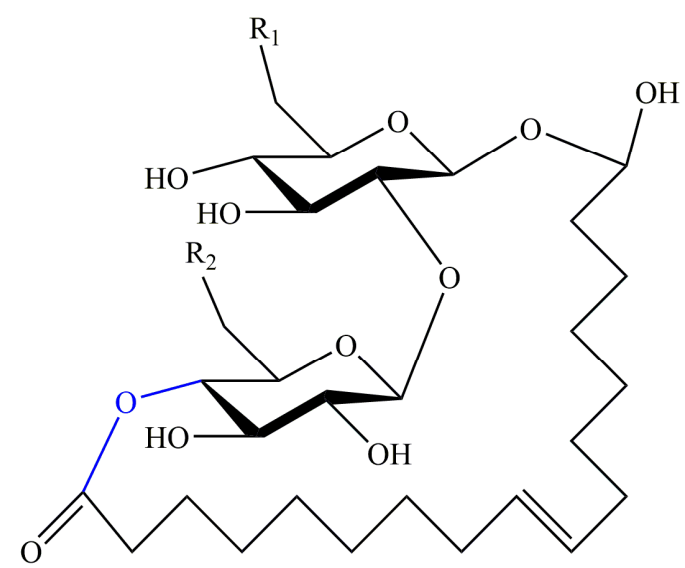

Acidic form

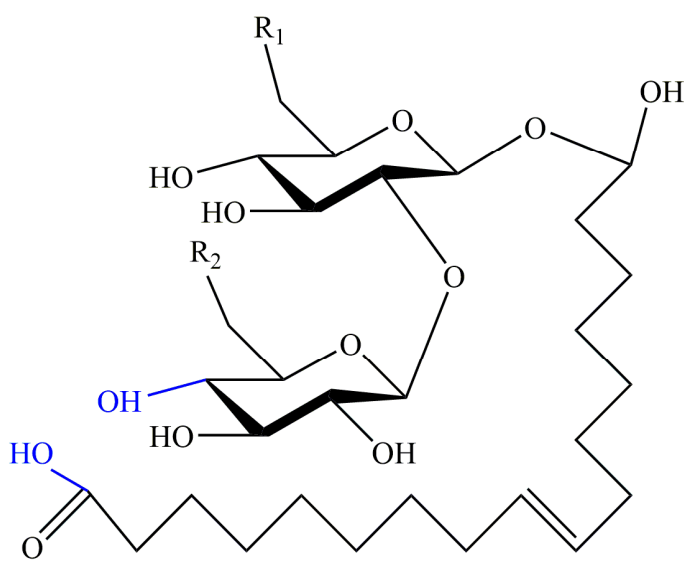

Figure 3. Common structures of sophorolipids: lactonic form and acidic form. $\mathrm{R}_{1}=\mathrm{OH}$ or $\mathrm{OCOCH}_{3}, \mathrm{R}_{2}=\mathrm{OH}_{\text {or }} \mathrm{OCOCH}_{3}$.

Sophorolipids have displayed diverse properties including emulsifier, lubricant, micelle formation, detergency, dispersibility, and wettability foaming, and their prominent antimicrobial activity has been deeply studied and applied in versatile field, seen in Table 2. Ankulkar et al. found semi-purified sophorolipids exhibited a different degree of antibacterial activity against pathogenic Escherichia coli, Listeria monocytogenes, and Staphylococcus aureus at minimum inhibitory concentrations (MIC) of 1000, 500, and $250 \mu \mathrm{g} / \mathrm{mL}$, respectively [51]. Similarly, Fontoura et al. found gram-positive bacteria (Enterococcus faecium, Staphylococcus aureus, and Streptococcus mutans) were proved to appear more sensitive to sophorolipids than gram-negative bacteria (Proteus mirabilis, Escherichia coli, Salmonella enterica subsp. enterica), with difference in treating dose of 500 and $2000 \mu \mathrm{g} / \mathrm{mL}$ [52]. Nevertheless, some researches depicted the potent killing efficacy on both types of strains and revealed the otherwise working mechanism. For instance, Gaur et al. discovered that $60 \mathrm{mg} / \mathrm{L}$ sophorolipids isolated from Candida glabrata CBS138 killed 65.8\% Bacillus subtilis and $4 \%$ Escherichia coli, and the further study confirmed the generation of reactive oxygen species (ROS) induced by sophorolipids has caused cell death [53].

For further practical application, sophorolipids were verified by Solaiman et al. to successfully inhibit the growth of five representative species of caries-causing oral bacteria: Lactobacillus acidophilus, Lactobacillus fermentum, Streptococcus mutans, Streptococcus salivarius, 
and Streptococcus sobrinus, suggesting the great potential of sophorolipids in oral health and hygiene [54]. Besides, sophorolipids have made contributions to reduce microbial contamination of Clostridium perfringens and Campylobacter jejuni in the poultry industry, which helps to lower enormous economic losses [55]. On the other hand, biofilm often fixes on the material surface such as medical devices, causes persistent microbial contamination and drug resistance, and has become prior trouble to be solved urgently. Recent research has revealed that sophorolipids have succeeded in scavenging biofilm of clinical strains (Staphylococcus aureus, Pseudomonas aeruginosa, and Candida albicans) on medical-grade silicone discs, resulting from their effective anti-adhesive ability [56]. Hence, there is immense potential to exploit sophorolipids as antimicrobial agents used in a variety of industries, such as poultry, food preservation, pharmaceutical industry, and medical apparatus and instruments.

Aiming at pathogenic fungi, sophorolipids also have a significant influence on spore germination, mycelial growth, and biofilm formation. Firstly, sophorolipids show a broad antifungal spectrum involving Colletotrichum gloeosporioides, Fusarium verticilliodes, Fusarium oxysporum f. sp. pisi, Corynespora cassiicola, and Trichophyton rubrum, reported by Suparna et al. [57]. Haque et al. described the inhibition of sophorolipids on hyphal growth and biofilm formation of Candida albicans, and thought the downregulation of hypha specific genes was the reason for blocking biofilm formation [58]. Later, in further study, they elucidated that sophorolipids have increased the ROS production and expression of oxidative stress-related genes significantly in Candida albicans, ultimately leading to cell death by membrane perforation and necrosis [59]. To biological control of plant disease, Chen et al. exposed sophorolipids have a restraining effect on spore germination and hyphal tip growth of various plant pathogens, and the result showed $\mathrm{pH}$ solubility of sophorolipids had influenced their efficacy [58]. For zoonotic dermatophyte, sophorolipids also exerted an antifungal and anti-biofilm effect on Trichophyton mentagrophytes and are likely to treat cutaneous mycoses [60].

Table 2. Antimicrobial effects of sophorolipids.

\begin{tabular}{|c|c|c|c|c|}
\hline Producing Microorganism & Target Microorganism & Microbial Type & Inhibitory Effects & Reference \\
\hline \multirow{2}{*}{ Candida glabrata CBS138 } & Bacillus subtilis & Gram-positive & \multirow{2}{*}{ Antibacterial effects } & \multirow{2}{*}[53]{} \\
\hline & Escherichia coli & Gram-negative & & \\
\hline \multirow{3}{*}{$\begin{array}{l}\text { Candida } \\
\text { tropicalis RA1 }\end{array}$} & Staphylococcus aureus & \multirow{2}{*}{ Gram-positive } & \multirow{3}{*}{ Antibacterial effects } & \multirow{3}{*}[51]{} \\
\hline & Listeria monocytogenes & & & \\
\hline & Escherichia coli & Gram-negative & & \\
\hline \multirow{6}{*}{ Candida bombicola } & Enterococcus faecium & \multirow{3}{*}{ Gram-positive } & \multirow{6}{*}{ Antibacterial effects } & \multirow{6}{*}[52]{} \\
\hline & Staphylococcus aureus & & & \\
\hline & Streptococcus mutans & & & \\
\hline & Proteus mirabilis, & \multirow{3}{*}{ Gram-negative } & & \\
\hline & Escherichia coli & & & \\
\hline & $\begin{array}{l}\text { Salmonella enterica subsp. } \\
\text { enterica }\end{array}$ & & & \\
\hline \multirow{5}{*}{$\begin{array}{l}\text { Candida bombicola ATCC } \\
22214\end{array}$} & Lactobacillus acidophilus & \multirow{5}{*}{ Gram-positive } & \multirow{5}{*}{ Antibacterial effects } & \multirow{5}{*}[54]{} \\
\hline & Lactobacillus fermentum & & & \\
\hline & Streptococcus mutans & & & \\
\hline & Streptococcus salivarius & & & \\
\hline & Streptococcus sobrinus & & & \\
\hline \multirow{2}{*}{$\begin{array}{l}\text { Starmerella (Candida) } \\
\text { bombicola }\end{array}$} & Clostridium perfringens & Gram-positive & \multirow{2}{*}{ Antibacterial effects } & \multirow{2}{*}[55]{} \\
\hline & Campylobacter jejuni & Gram-negative & & \\
\hline
\end{tabular}


Table 2. Cont.

\begin{tabular}{|c|c|c|c|c|}
\hline Producing Microorganism & Target Microorganism & Microbial Type & Inhibitory Effects & Reference \\
\hline Candida bombicola & Escherichia coli & Gram-negative & Antibacterial effects & [61] \\
\hline \multirow{3}{*}{$\begin{array}{l}\text { Candida bombicola ATCC } \\
22214\end{array}$} & Staphylococcus aureus & Gram-positive & \multirow{3}{*}{ Anti-biofilm effects } & \multirow{3}{*}{ [56] } \\
\hline & Pseudomonas aeruginosa & Gram-negative & & \\
\hline & Candida albicans & Fungi & & \\
\hline $\begin{array}{l}\text { Starmerella (Candida) } \\
\text { bombicola MTCC1910 }\end{array}$ & Candida albicans & Fungi & $\begin{array}{l}\text { Antifungal and } \\
\text { anti-biofilm effects }\end{array}$ & {$[58,59]$} \\
\hline \multirow{5}{*}{ Rhodotorula babjevae YS3 } & $\begin{array}{l}\text { Colletotrichum } \\
\text { gloeosporioides }\end{array}$ & \multirow{5}{*}{ Fungi } & \multirow{5}{*}{ Antifungal effects } & \multirow{5}{*}[57]{} \\
\hline & Fusarium verticilliodes & & & \\
\hline & $\begin{array}{l}\text { Fusarium oxysporum } f . \mathrm{sp} \text {. } \\
\text { pisi }\end{array}$ & & & \\
\hline & Corynespora cassiicola & & & \\
\hline & Trichophyton rubrum & & & \\
\hline \multirow{10}{*}{ Wickerhamiella domercqiae $\mathrm{Y} 2 \mathrm{~A}$} & Phytophthora infestans & \multirow{10}{*}{ Fungi } & \multirow{10}{*}{$\begin{array}{l}\text { Inhibiting spore } \\
\text { germination and mycelial } \\
\text { growth }\end{array}$} & \multirow{10}{*}[60]{} \\
\hline & Fusarium sp. & & & \\
\hline & Fusarium concentricum & & & \\
\hline & Fusarium oxysporum & & & \\
\hline & Pythium ultimum & & & \\
\hline & Pyricularia oryzae & & & \\
\hline & Rhizoctorzia solani & & & \\
\hline & Alternaria kikuchiana & & & \\
\hline & $\begin{array}{l}\text { Gaeumannomyces graminis } \\
\text { var. tritici }\end{array}$ & & & \\
\hline & Phytophthora infestans & & & \\
\hline Rhodotorula babjevae YS3 & Trichophyton mentagrophytes & Fungi & $\begin{array}{l}\text { Antifungal and } \\
\text { anti-biofilm effects }\end{array}$ & [62] \\
\hline
\end{tabular}

\subsection{Mannosylerythritol Lipids}

Mannosylerythritol lipids (MELs) are a type of glycolipid biosurfactants produced by Pseudozyma species mainly as well as Ustilago species [63]. Mannosylerythritol lipids were initially found and characterized in Ustilago zeae in the 1950s, but relevant researches were limited and unfocused in the following thirty years [64]. After the 1980s, a variety of strains were isolated as MEL-producers based on substrates of glucose and oil, such as Pseudozyma antarctica, Pseudozyma tsukubaensis, and Pseudozyma hubeiensis [65-67]. The basic molecular structure was composed of the mannose molecule linked to an erythritol residue at C-1' and two fatty acids at the C-2' and C- $3^{\prime}$ [68]. Due to the different position and quantity of acetyl groups, these compounds can be divided into four groups: MEL-A (diacetylated at C-4 $4^{\prime}$ and C-6 $6^{\prime}$ ), MEL-B (monoacetylated at C- $\left.6^{\prime}\right)$, MEL-C (monoacetylated at C- $4^{\prime}$ ), and MEL-D (deacetylated) [69], shown in Figure 4. According to the literature, the structure of MEL depends on the carbon source primarily, and structural diversity confers to multiple interfacial and biological properties including emulsibility, non-toxicity, anti-cancer, and antioxidant activity, biodegradability, anti and environmental compatibility, showing their great application prospects in medical, environmental, cosmetic, pharmaceutical and food industries [70]. 
MEL-A

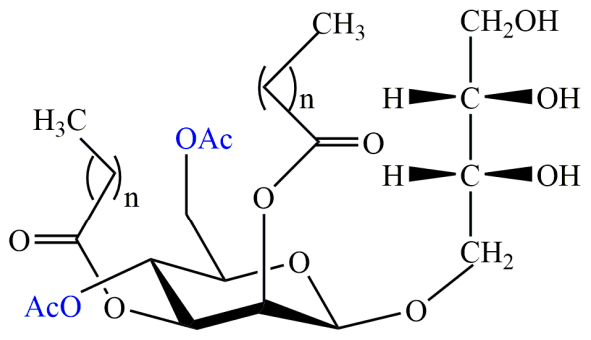

MEL-C

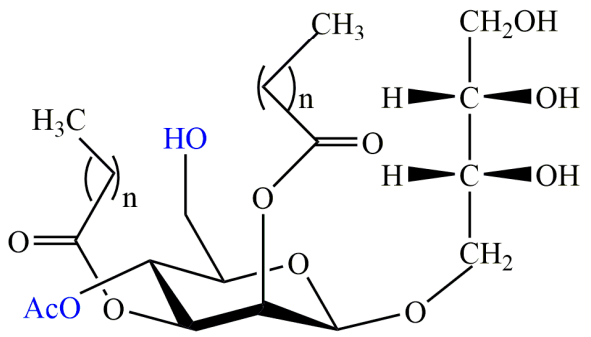

MEL-B

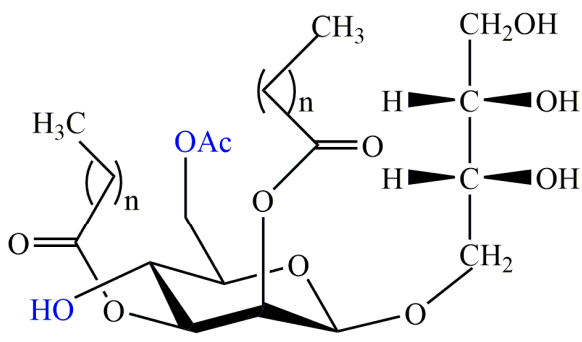

MEL-D

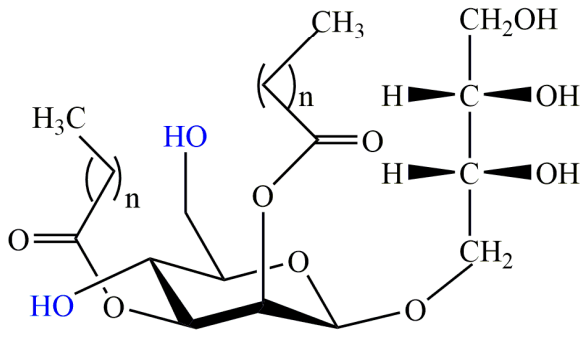

Figure 4. Different structures of mannosylerythritol lipids: Mannosylerythritol lipid (MEL)-A, MEL-B, MEL-C, and MEL-D, $n=2 \sim 18$

The bactericidal effects of MELs are of vital importance in their practical applications, as listed in Table 3. In 1993, Kitamoto et al. firstly pointed out that MELs showed significant antimicrobial activity, especially against Gram-positive bacteria [71]. Then, Fukuoka et al. also stated MEL-A and MEL-B have performed high inhibitory effects on Micrococcus luteus, and the reason was attributed to their solubilizing effect on bilayer biomembranes [72]. Similarly, the growth of gram-positive bacteria (Bacillus megaterium and Bacillus subtilis) was restrained by MEL-A and MEL-B reported by Recke et al., and they also found MELs showed moderate antifungal effects on Candida magnoliae [73]. Besides, Okuhira et al. compared the antimicrobial effects of MEL against two types of bacteria and summarized MEL selectively inhibited the proliferation of most gram-positive bacteria below the concentration of $50 \mu \mathrm{g} / \mathrm{mL}$, but not gram-negative bacteria [74]. Furthermore, Nashida et al. synthesized 20 congeners of MELs through a chemical process and compared their inhibition on microbes, and the results illustrated not only the length of the alkyl chains but also the pattern of Ac groups on the mannose moiety were important factors for antibacterial activity [75].

So far, it has been reported that MELs have exhibited excellent sterilizing impact on foodborne bacteria and is expected to be a novel safe alternative to food preservative in food storage. Shu et al. investigated the antibacterial efficacy of MELs against Bacillus cereus and Staphylococcus aureus and concluded the mode of action involved the disruption of the cell membrane, leakage of cellular contents, the collapse of the whole cytoskeleton as well as induced cell apoptosis [76,77]. Liu et al. observed the same phenomenon in Listeria monocytogenes treated by MEL-A $(32 \mu \mathrm{g} / \mathrm{mL})$, and further transcriptome analysis demonstrated that the differentially expressed genes were enriched in the $A B C$ transporter system, which verified the disorder of transmembrane protein played a key role in MELmediated cell death [78].

It is worth mentioning MELs are able to reduce the persistent contamination caused by fungi growth and microbial biofilm. For example, Yoshida et al. exposed the suppressive effects of MELs on the early infection behaviors of several phytopathogenic fungal conidia including Blumeria graminis f. sp. tritici (wheat powdery mildew fungi), Colletotrichum dematium (mulberry anthracnose fungi), Glomerella cingulata (strawberry anthracnose fungi), and Magnaporthe grisea (rice blast fungi), presumably owing to their inhibition to conidial 
germination, and anticipated the future application of MELs as novel agricultural chemical pesticides [79]. On the other hand, it is evident that MELs showed potent anti-biofilm activity against Staphylococcus aureus through attachment inhibition and biofilm dispersal, which was explained as the involvement of biosurfactants in microbial adhesion and desorption $[77,80]$.

Table 3. Antimicrobial effects of mannosylerythritol lipids.

\begin{tabular}{|c|c|c|c|c|}
\hline Producing Microorganism & Target Microorganism & Microbial Type & Inhibitory Effects & Reference \\
\hline Pseudozyma aphidis T-34 & Micrococcus luteus & Gram-positive & Antibacterial effects & [72] \\
\hline \multirow{4}{*}{$\begin{array}{l}\text { Pseudozyma aphidis CBS } \\
517.83\end{array}$} & Bacillus megaterium & \multirow{3}{*}{ Gram-positive } & \multirow{4}{*}{ Antibacterial effects } & \multirow{4}{*}{ [73] } \\
\hline & Bacillus subtilis & & & \\
\hline & Staphylococcus aureus & & & \\
\hline & Candida magnoliae & Fungi & & \\
\hline Pseudozyma aphidis & Bacillus cereus & Gram-positive & Antibacterial effects & [76] \\
\hline $\begin{array}{l}\text { Pseudozyma aphidis DSM } \\
70725\end{array}$ & Staphylococcus aureus & Gram-positive & $\begin{array}{l}\text { Antibacterial and } \\
\text { anti-biofilm effects }\end{array}$ & [77] \\
\hline \multirow[t]{5}{*}{$\begin{array}{l}\text { Pseudozyma aphidis DSM } \\
70,725\end{array}$} & Listeria monocytogenes & Gram-positive & Antibacterial effects & [78] \\
\hline & Micrococcus luteus & \multirow{4}{*}{ Gram-positive } & \multirow{4}{*}{ Antibacterial effects } & \multirow{4}{*}{ [75] } \\
\hline & Staphylococcus aureus & & & \\
\hline & Enterococci faecalis & & & \\
\hline & Enterococci faecium & & & \\
\hline \multirow{6}{*}{$\begin{array}{l}\text { Pseudozyma aphidis NBRC } \\
10182\end{array}$} & Streptococcus bovis, & \multirow{6}{*}{ Gram-positive } & \multirow{6}{*}{ Antibacterial effects } & \multirow{6}{*}{ [74] } \\
\hline & Lactobacillus ruminis & & & \\
\hline & Eubacterium ruminantium & & & \\
\hline & Butyrivibirio fibrisolvens & & & \\
\hline & Ruminococcus albus & & & \\
\hline & Ruminococcus flavefaciens & & & \\
\hline Lactobacillus casei & Staphylococcus aureus & Gram-positive & Anti-biofilm effects & [80] \\
\hline \multirow{4}{*}{ Pseudozyma yeast } & $\begin{array}{l}\text { Blumeria graminis } f . \mathrm{sp} \text {. } \\
\text { tritici }\end{array}$ & \multirow{4}{*}{ Fungi } & \multirow{4}{*}{$\begin{array}{l}\text { Inhibition of conidial } \\
\text { germination. }\end{array}$} & \multirow{4}{*}{ [79] } \\
\hline & Colletotrichum dematium & & & \\
\hline & Glomerella cingulata & & & \\
\hline & Magnaporthe grisea & & & \\
\hline
\end{tabular}

\subsection{Cellobiose Lipids}

Cellobiose lipids (CLs) are a kind of glycolipid biosurfactants with less research than other glycolipids. In 1951, cellobiose lipids were firstly reported as ustilagic acid (UA) with antibiotic activity, produced by phytopathogenic fungi Ustilago maydis [81], and the structure was then characterized as three forms: CL A, CL B, and CL C, shown in Figure 5 [82]. Subsequent researches have revealed a diversity of CL-producers including Cryptococcus huminola, Pseudozyma fusiformata [83], Pseudozyma graminicola [84], Pseudozyma. flocculosa [85], and Sporisorium scitamineum [86] cultivated on glucose, vegetable oil, and alkane. The basic structure of cellobiose lipids consist of a cellobiose moiety as the hydrophilic group and a fatty acid chain as the hydrophobic group, and the variants can differ in the presence or absence of hydroxyl group $(\mathrm{R}=\mathrm{H}$ or $\mathrm{OH})$ or the length of fatty acid chain as well as an additional easter group (CL C) [82]. The studies suggest the structure of 
cellobiose lipids is determined by their producing microorganisms. Cellobiose lipids have the advantage of biodegradability, low toxicity, emulsibility, surface activity, a wide range of $\mathrm{pH}$ tolerance and thermostability over chemical surfactants, and have great potential employed in the food industry, medical field, and environmental protection.

CL-A

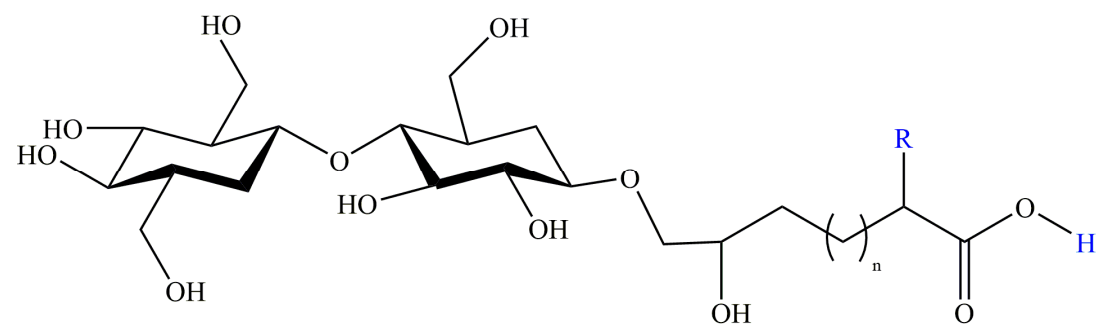

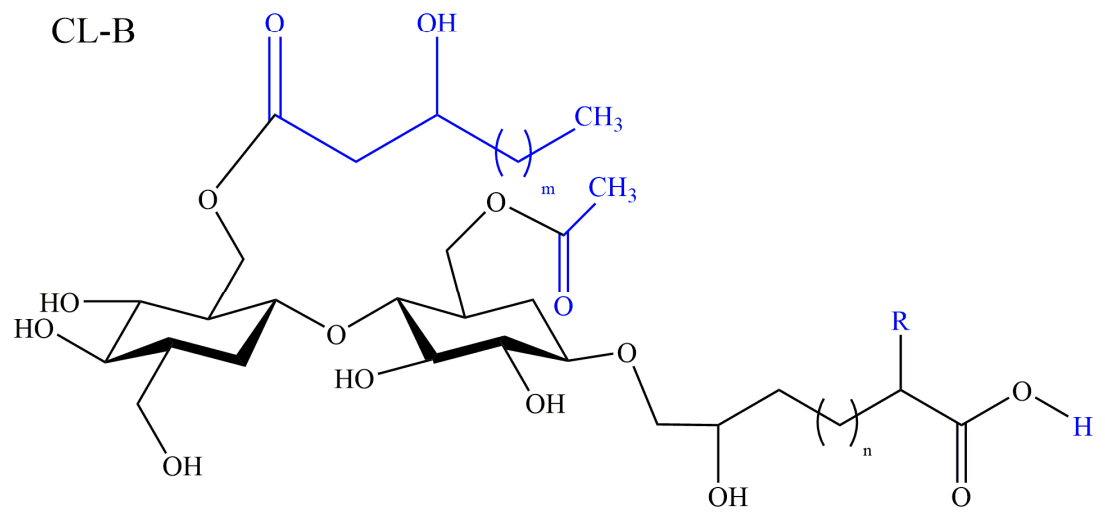

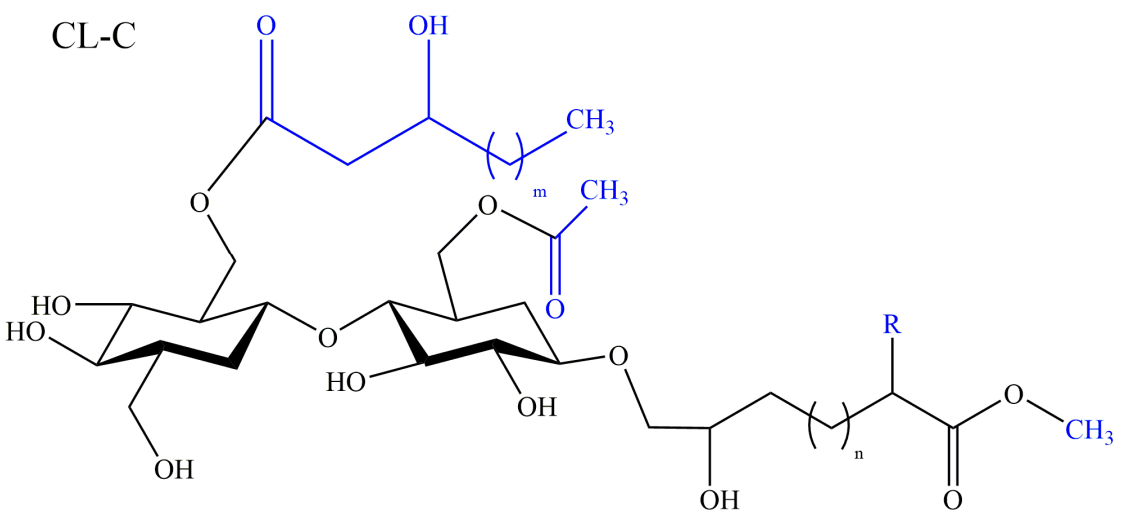

Figure 5. Structures of cellobiose lipids isolated from Ustilago maydis: CL-A, CL-B, and CL-C. R = H or $\mathrm{OH}, m=2$ or 4 .

The antifungal activity of cellobiose lipids has been investigated thoroughly since Haskins et al. firstly discovered the antibiotic activity of ustilagic acid (namely cellobiose lipids) in 1951 [81]. The targeting fungi contains yeast and filamentous fungi, such as Saccharomyces cerevisiae [87], Cryptococcus, and Candida species [83], and the underlying antifungal mechanism is always associated with the structural and functional disorder of cell membrane caused by cellobiose lipids. For instance, Puchkov et al. illuminated that the intercalation of cellobiose lipids into the liposomal lipid matrix resulted in the increasing permeabilization of cytoplasmic membrane, ATP leakage, and high susceptibility of targeted cells, and considered this antifungal mode of action was relevant to detergent-like properties [88]. This membrane-damaging activity of cellobiose lipids was also proven 
by Kulakovskaya et al. that CL has induced $\mathrm{K}^{+}$leakage and inhibited polyphosphate accumulation in Saccharomyces cerevisiae cells [89]. Moreover, further study displayed the sensitivity of Saccharomyces cerevisiae cells to antifungal cellobiose lipids is up to culturation components, especially carbon source, and speculated that the long-chained polyP participated in the viability restoring of ethanol-grown cells after treated by cellobiose lipids [87]. Besides, flocculosin is known as one of the effective components in biological control agents of powdery mildew fungi and has been confirmed to show inhibitory effects on pathogenic fungi, and further work revealed that flocculosin caused direct damage to the membrane surface of sensitive micro-organisms, such as Staphylococcus species and Candida albicans, which implied the membrane-mediated antimicrobial mechanism was suitable for gram-positive bacteria [90,91]. Consequently, CLs are defined as a novel safe and natural fungicide more exactly and allowed to become membrane-penetrating agents against yeast and fungal cells.

\section{Glycolipid-Modified Materials}

\subsection{Nanocomposites}

Nanotechnology is a new burgeoning technology dealing with nanoscale dimensions of particles that can produce novel multifunctional materials and devices with a variety of applications. The size of nanoparticles ranges from 1 to $100 \mathrm{~nm}$ and the combination of two or more compounds of materials, in which at least one compound has a dimension less than $100 \mathrm{~nm}$ in size, can be defined as nanocomposites [92]. Compared to normal materials, nanocomposites have the advantage of physicochemical and combined biological properties and have attracted interest in various technological and environmental areas such as medicine, energy, cosmetics, electronics, packaging, coatings, and biotechnology. As a carrier, nanocomposites are able to deliver substances such as drugs and achieve the effect of target therapy and release control, which have great potential in practical applications of antitumor therapy [93]. The synthesis of nanocomposites is usually based on chemical and physical methods, while the former is the most widely adopted and highly efficient for largescale and high-performance production of nanocomposites. Nevertheless, the nanoparticles are often synthesized along with hazardous and toxic byproducts during the chemical process, which may pose a threat to public hygiene and environment. As a multifunctional agent, biosurfactants have gradually gained more attention in recent years and played a crucial role in the green synthesis of nanocomposites as seen in Figure 6, owing to their superior biocompatibility, biodegradability, high efficiency of stabilization, and dispersion. Firstly, biosurfactants could enhance the stability of nanocomposites by reducing the interfacial tension and facilitating nanoemulsion formation. Furthermore, the presence of biosurfactants prevents nanoparticles from aggregation and promotes dispersion in organic solvents or water as a capping agent. On the other hand, biosurfactants could act as a reducing agent in the synthesis of nanocomposites, which effectively simplifies the producing procedures with better control [94]. Except for their physical characteristics, biosurfactants will improve the biological properties of nanocomposites as a functional adjuvant involving antioxidant, antimicrobial, and anticancer effects.

In the past decade, the rapid development of nanotechnology has been emphasized and provided more opportunities in the antimicrobial field. Nanomaterials have been proved to be effective to inhibit cell growth of various microorganisms even multi-drugresistant bacteria, and show less possibility to induce microbial resistance [95]. According to the literature, the antimicrobial modes could be summarized as increasing cell membrane permeability, inhibiting efflux pump, and generating reactive oxygen species (ROS) [96,97]. Therefore, glycolipids, as a typical kind of biosurfactants, have been employed in nanomaterial production due to their excellent emulsifying and antimicrobial properties, as listed in Table 4.

Das et al. reported that rhamnolipids could be used to stabilize the synthesis of silver nanoparticles, and the antibacterial and antifungal activity of both silver nanoparticles and purified rhamnolipids against four strains of bacteria (Staphylococcus aureus, Bacillus 
subtilis, Escherichia coli, and Klebsiella pneumoniae) and two fungi (Aspergillus niger and Aspergillus flavus) was studied [98]. The comparative result suggested silver nanoparticles are more effective when inhibiting the microbial growth of all kinds than purified rhamnolipids. Joanna et al. also synthesized silver nanoparticles (AgNPs) through chemical and biological processes, respectively, and discovered the existence of rhamnolipid significantly increased the stability of biogenic AgNPs and enhanced their antimicrobial activities [99]. The rhamnolipid-involved biogenic AgNPs exhibited more effective inhibition on grampositive bacteria and phytopathogenic fungi than gram-negative bacteria, probably owing to the difference in bacterial membrane structure. Furthermore, the interactions between biogenic AgNPs and DNA were investigated and the DNA particles were significantly observed to accumulate around the AgNPs densely, potentially due to the strong affinity between metal nanoparticles and nitrogen bases with the hydrogen bonds. On the other hand, rhamnolipids help to stabilize the meatal nano-carrier when encapsulating various substances, such as carvacrol [100]. The rhamnolipid-stabilized carvacrol-loaded zein nanoparticles have been verified to suppress the growth of phytopathogens Pseudomonas syringae and Fusarium oxysporum, which might result from the synergistic antimicrobial effects of carvacrol, zein, and rhamnolipids.

Interestingly, there is often a win-win situation that glycolipid-modified nanocomposites exert potent inactivating function against both planktonic cells and persistent biofilm. Marangon et al. elucidated that a combination of rhamnolipid and chitosan in nanoparticles boosts their antimicrobial efficacy on Staphylococcus strains, and the reason was attributed to the increased local delivery of chitosan and rhamnolipid at the cell surface and, consequently, to their targets in gram-positive bacteria [101]. Especially, although chitosan could not penetrate deeply in the biofilm through adsorption on the surface, the nanoparticles enabled the antibacterial rhamnolipid to release and fill the whole biofilm, rendering devastation of the biofilm structure and death of dormant cells. Another mechanism of biofilm eradication for nanomaterials is based on the anti-adhesive property of glycolipid biosurfactant, and it has been reported that rhamnolipid-coated silver and $\mathrm{Fe}_{3} \mathrm{O}_{4}$ nanocomposites exert more anti-biofilm efficacy against pathogenic Pseudomonas aeruginosa and Staphylococcus aureus than individual RL or bare nanoparticles [97].

Sophorolipids could also participate in the fabrication of nanomaterials and be considered as dual roles including a biostabilizer and a biofunctionalizing agent. For instance, zinc oxide nanoparticles (ZON) modified by sophorolipids have shown stronger inhibitory activity against Salmonella enterica and Candida albicans compared with naked ZON [96]. Generally, gram-positive bacteria reveal more sensitivity to sophorolipids than gramnegative bacteria, while sophorolipid capped gold nanoparticles (AuNPs-SL) exhibited antibacterial properties against both gram-positive and gram-negative bacteria via binding to cell membrane, disintegrating cell membrane, leaking intracellular constituents, and interfering the enzyme activity [102]. Aiming at biofilm elimination, the acidic sophorolipid was used to encapsulate hydrophobic curcumin in order to form nanostructures with better dispersibility in water [102]. The sophorolipid-curcumin nanocomposites have the capability to scavenge the biofilm of Pseudomonas aeruginosa as a quorum quencher.

Although the researches of MELs involved in nanomaterial synthesis are not as many as others, their applications in nanotechnology are emerging and advancing latterly. Firstly, Wu et al. embedded chitosan nanoparticles into essential oils using MEL-A as an emulsifier and observed an apparent inhibition zone against Staphylococcus aureus around the chitosan-based nanoparticles [103]. Subsequently, Bakur et al. successfully fabricated metallic nanomaterials including silver, zinc oxide, and gold nanoparticles mediated by MEL-A, and all of them exert inhibitory efficacy against pathogenic gram-positive and gram-negative bacteria [104]. These findings indicated that MELs play a crucial role in the rapid biosynthesis of metallic nanoparticles and enhance the antimicrobial property, yet the underlying mechanism of inhibition still needs further study. 


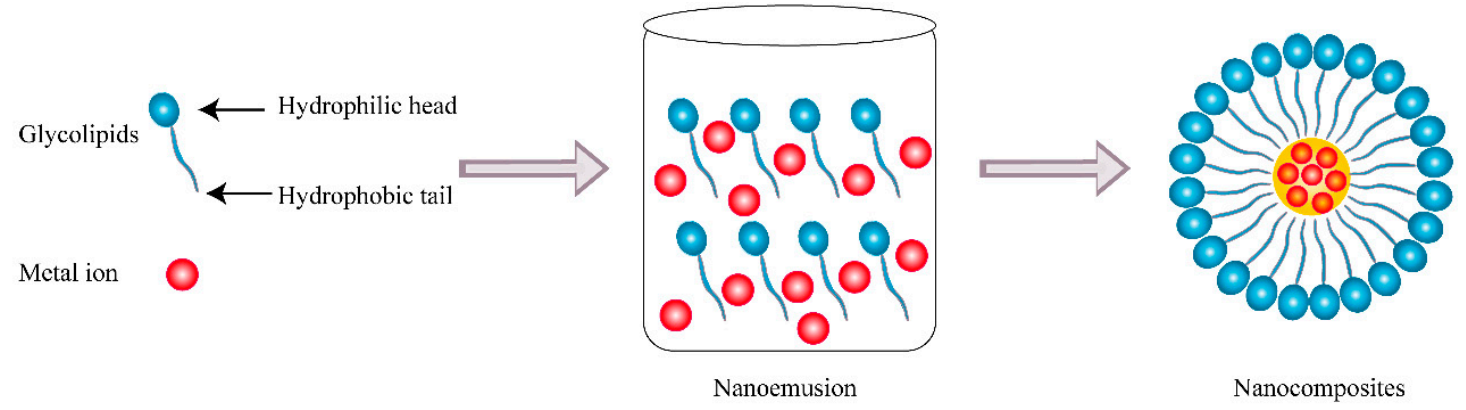

Figure 6. Schematic diagram of the synthetic pathway of nanocomposites based on glycolipids.

Table 4. Antimicrobial effects of glycolipid-modified nanocomposites.

\begin{tabular}{|c|c|c|c|}
\hline Name & Glycolipid Type & Antimicrobial Effects & Reference \\
\hline $\begin{array}{l}\text { Rhamnolipid-stabilized } \\
\text { carvacrol-loaded zein } \\
\text { nanoparticles }\end{array}$ & Rhamnolipid & $\begin{array}{l}\text { Antibacterial and antifungal activity } \\
\text { against Pseudomonas syringae and } \\
\text { Fusarium oxysporum. }\end{array}$ & [100] \\
\hline Silver nanoparticles & Rhamnolipid & $\begin{array}{l}\text { Antibacterial and antifungal activity } \\
\text { against Staphylococcus aureus, Bacillus } \\
\text { subtilis, Escherichia coli and Klebsiella } \\
\text { pneumoniae, Aspergillus niger, and } \\
\text { Aspergillus flavus. }\end{array}$ & [98] \\
\hline AgNPs & Rhamnolipid & $\begin{array}{l}\text { Antibacterial activity against } \\
\text { gram-positive bacteria and antifungal } \\
\text { activity against phytopathogens. }\end{array}$ & [99] \\
\hline Silver and iron oxide nanoparticles & Rhamnolipid & $\begin{array}{l}\text { Antibacterial and anti-adhesive } \\
\text { properties against biofilms formed by } \\
\text { Pseudomonas aeruginosa and } \\
\text { Staphylococcus aureus. }\end{array}$ & [97] \\
\hline Chitosan/rhamnolipid nanoparticles & Rhamnolipid & $\begin{array}{l}\text { Antibacterial and anti-biofilm activity } \\
\text { against Staphylococcus strains. }\end{array}$ & [101] \\
\hline ZnO Nanoparticle & Sophorolipid & $\begin{array}{l}\text { Antibacterial activity against Salmonella } \\
\text { enterica and Candida albicans. }\end{array}$ & [96] \\
\hline $\begin{array}{l}\text { Curcumin-sophorolipid } \\
\text { nanostructures }\end{array}$ & Sophorolipid & $\begin{array}{l}\text { Antibacterial activity anti-biofilm activity } \\
\text { against Pseudomonas aeruginosa. }\end{array}$ & [105] \\
\hline Gold Nanoparticles & Sophorolipid & $\begin{array}{l}\text { Antibacterial and anti-biofilm effects on } \\
\text { Staphylococcus aureus and Vibrio cholerae }\end{array}$ & [102] \\
\hline Chitosan Nanoparticles & MEL-A & $\begin{array}{l}\text { Antibacterial activity against } \\
\text { Staphylococcus aureus }\end{array}$ & [103] \\
\hline $\begin{array}{l}\text { MEL@AgNPs, MEL@ZnONPs and } \\
\text { Ag-ZnO/MEL/GA }\end{array}$ & MEL-A & $\begin{array}{l}\text { Antibacterial activity against Escherichia } \\
\text { coli, Salmonella enterica, Bacillus cereus and } \\
\text { Staphylococcus aureus. }\end{array}$ & [106] \\
\hline Gold nanoparticles (AuNPs) & MEL-A & $\begin{array}{l}\text { Antibacterial activity against } \\
\text { gram-positive and gram-negative } \\
\text { bacteria. }\end{array}$ & [104] \\
\hline
\end{tabular}

\subsection{Liposomes}

Liposomes are small spherical vesicles and normally possess a closed lipid bilayer resembling a cell membrane and an aqueous inner chamber, which could encapsulate hydrophilic and hydrophobic molecules, respectively. As multifunctional drug-carriers, liposomes have the advantages of biocompatibility, stability, membrane fusion, gene transfection, controlled release, and entrapment protection, widely applied in pharmaceutical, cosmetics, and food fields [107]. There is a diversity of liposome structures including single 
or multiple lipid bilayers, and one or more compartments. The variations of their properties are depending on the composition, size, surface charge, and producing method. The size of liposomes is ranging from nanometers to micrometers, and it will be called nanoliposome when the size is less than $100 \mathrm{~nm}$. Since the first liposome Doxil ${ }^{\circledR}$ was approved by FDA for cancer therapy in 1995, there are more and more FDA-approved liposome-based pharmaceuticals applied into clinical treatments in the following decades, involving anticancer, antimicrobial, and antiviral therapies [108]. For example, rifampicin-loaded liposomes were frequently reported [109]. For lung inhalation therapy, a polyelectrolyte complex based on chitosan and carrageenan was used to coat rifampicin-loaded vesicles and obtain a dry powder by spray-drying [110]. Furthermore, inhalable polymer-glycerosomes were proved to be safe and effective carriers for rifampicin delivery to the lungs, which enhanced the local pharmacological activity of rifampicin, reduced possible side effects, and improved drug efficacy [111].

Thereby, the broad encapsulating properties of liposomes come up with a novel strategy to inactivate microorganisms with reduced resistance. It is easy for natural or synthetic antimicrobial agents incorporated in liposomes to reach intracellular targets via the fusion of lipid bilayer and cell membrane, hence exerting high therapeutic efficacy. Therefore, glycolipids could be embedded into liposomes together with other bactericides, thereby realizing multiple antimicrobial effects on gram-positive, gram-negative, and fungi. Nevertheless, this research direction has been rarely investigated.

Except for acting as bioactive substances, glycolipids are able to self-assemble as a closed lipid bilayer, and the formed spherical vesicles are orderly arranged through exposed hydrophilic glycosyls and tail-to-tail hydrophobic fatty acid chains. Interestingly, MELs specialize in self-assembly properties and form vesicle structure with thermodynamic stability, and have great potential to participate in liposome fabrication and stabilize the bilayer structure [112]. For example, Wu et al. demonstrated the chitosan-coated liposome with loading betulinic acid was modified by MEL-A, and the results implied MEL-A boosted the antioxidant effect of betulinic acid [113]. Fan et al. successfully prepared stable vesicles consisting of L- $\alpha$-phosphatidylcholine (PC) and MEL-A by a thin lipid film hydration technique and evaluated their structural characterization, stability, and encapsulation efficiency [114]. The consequence showed the addition of MEL-A changed the dispersibility of PC in water, rendering the formation of vesicle solution with smaller size and higher encapsulation efficiency. Moreover, anthocyanins embedded in vesicles exhibited improved antioxidant activity and higher retention rate in simulated gastrointestinal fluid environment than bare anthocyanins, mainly owing to the protection of vesicles. In the antimicrobial field, sophorolipid has been reported to formulate noisome with amphotericin B, and the complex was proved to inhibit the growth of planktonic cells and destruct mature biofilm of Candida albicans, presumably through downregulating expressions of the genes responsible for hyphae formation [115]. These findings anticipate the prospective development of liposomes based on glycolipids.

\section{Conclusions and Perspectives}

Glycolipids, as a kind of representative biosurfactants, are famous for versatile bioactivities and have immerse potential to be put into practical applications due to their environmental friendliness compared to chemical surfactants. Deep insight into the predominant antimicrobial behaviors of glycolipids reveals several underlying mechanisms when targeting planktonic or biofilm state of microorganisms, as seen in Figure 7, which provides a theoretical basis for exploiting novel safe antimicrobial agents applied in food, cosmetics, and medical fields. The induced death of a single cell could be attributed to the following reasons. The membrane permeabilization is considered as the prior factor leading to cell lysis and apoptosis. Specifically, glycolipids are able to insert into the lipid bilayer relying on their unique similar structure, leading to the deformation and collapse of membrane skeleton physically as well as a conformational change of related proteins functionally. As the main member of membrane proteins, ATP-binding cassette 
$(\mathrm{ABC})$ transporters are responsible for transmembrane migration of material and energy transformation via ATP hydrolysis, and it has been proven that glycolipids have rendered the disorder of movement across the membrane and material supplement by regulating the different expression of related genes, which might be internal reason accounting for the final cell apoptosis $[78,116]$. Except for membrane-mediated modes, correlational researches also discovered the generation of ROS in bacteria and fungi [53,59]. Generally, it is a common phenomenon that ROS is generated by normal cells during oxygen respiration and metabolism, while ROS production is increased due to redox-cycling agents, membrane disrupters, and antibiotics [117]. As a result, oxidative stress emerges when a cell is not able to detoxify the excessively accumulated ROS, leading to cell death by necrosis or apoptosis. On the other hand, eliminating refractory microbial contamination caused by persistent and resistant biofilm has become a huge challenge to be solved urgently. Glycolipid-involved strategy to tackle microbial biofilm is mainly aiming at blocking the adhesive stage and promoting the dispersal stage during the biofilm formation [118]. The anti-adhesive behavior can be attributed to the intrinsic antimicrobial and physiochemical characteristics of glycolipids, causing reduction of the cell density and changes in hydrophilic/hydrophobic characteristics of treated surfaces. The promotion of biofilm dispersal is related to the permeation of glycolipids into the biofilm matrix, resulting in detachment of extracellular matrix (EPS) and disintegration of the whole biofilm community. Although glycolipids play extraordinary roles in antimicrobial work, they behave less friendly in the human immune system. The literature revealed rhamnolipids has functioned as immune modulators and virulence factors, leading to rapid necrotic killing of polymorphonuclear leukocytes [119], early infiltration of primary human airway epithelia [120], and killing the myofibroblasts [118].

\section{Extracellular}

- Glycolipids

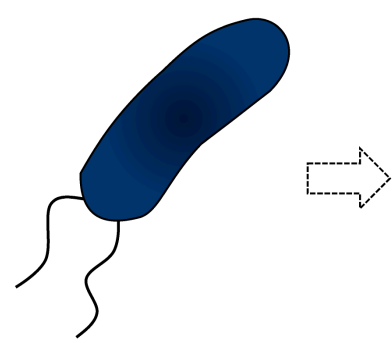

Single bacteria

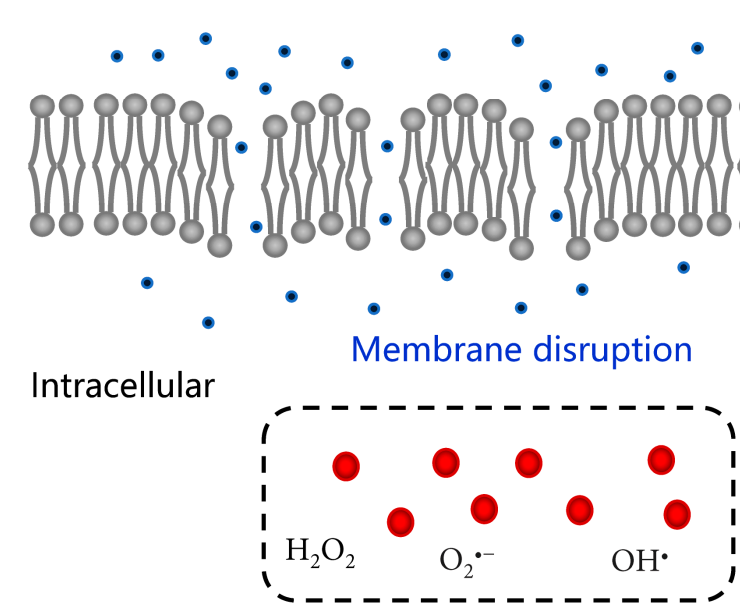

ROS generation

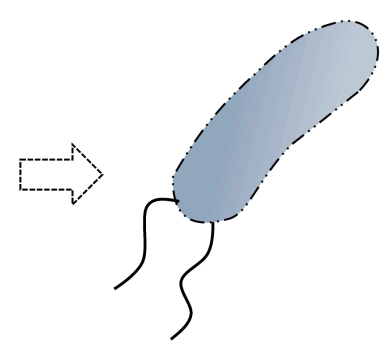

Cell apoptosis

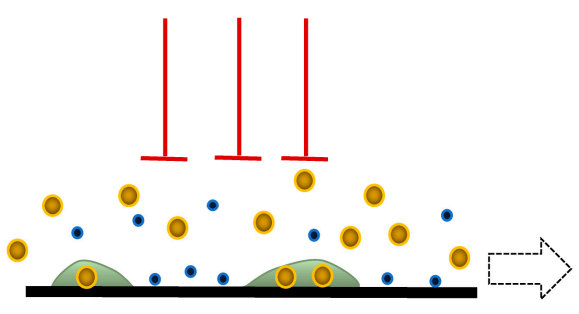

Inhibiting adhesion

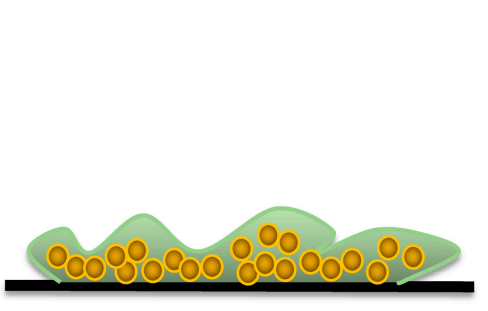

Mature biofilm

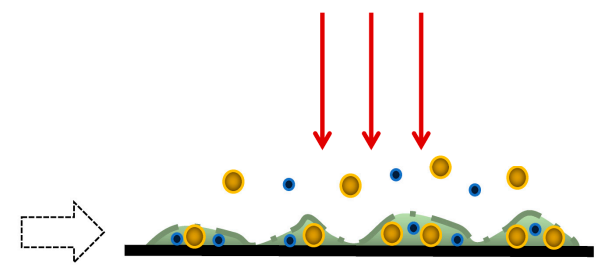

Promoting detachment

Figure 7. Schematic diagram of the antimicrobial mechanism of glycolipids involved in planktonic cells and biofilms. 
Nano-scale approaches have been rapidly progressed and attract concentration globally on controlling microbial contamination in medical and healthcare applications. Nanocarriers (such as nanoparticles and liposomes) are regarded as crucial drug delivery systems due to their great dispersity, high encapsulation efficiency, and stability. Glycolipids have been reported to play an important role in the modification of these materials both structurally and functionally, relying on their special amphipathicity and self-assembling activity as well as various biological activities. Therefore, the antimicrobial effect of glycolipidmodified material has been augmented evidently because of the combination of effective compounds. The modification of new materials based on glycolipids prompts the exploitation of novel antimicrobial agents applicable to different requirements.

Furthermore, the synergic work of glycolipids and antibiotics or other antimicrobials on microorganisms is on trial and has made initial progress. Sophorolipids was confirmed to work co-jointly with tetracycline to cause swelling and morphological damage of methicillin-resistant Staphylococcus aureus [119]. The underlying mechanism was speculated that the self-assembled glycolipids could span through the structurally alike bacterial cell membrane and thereby facilitate the entry of antibiotics [120]. At present, antimicrobial resistance has posed a serious threat to public health and hygiene, leading to an increasing number of ineffective antibiotics. Nevertheless, developing new antibiotics is time- and money-consuming, and difficult, which has the risk of new drug-resistance emerging. Hence, the great potential of glycolipids to attenuate microbial resistance will be a hot spot and presents a new strategy to inactivate drug-resistant microorganisms via the synergy of antibiotics and glycolipids, which will make a break in the antimicrobial field.

Author Contributions: Investigation, H.L. and Q.S.; resources, T.W. and Q.S.; data curation, X.L. and Q.S.; writing—original draft preparation, Q.S.; writing—review and editing, Q.C. All authors have read and agreed to the published version of the manuscript.

Funding: This study was financially supported by Public Projects of Zhejiang Province (LGF18C200003), National Key Research and Development Program of China (2018YFC1200100) China.

Institutional Review Board Statement: Not applicable.

Informed Consent Statement: Not applicable.

Conflicts of Interest: The authors declare no conflict of interest.

\section{References}

1. Paulino, B.N.; Pessoa, M.G.; Mano, M.C.; Molina, G.; Neri-Numa, I.A.; Pastore, G.M. Current status in biotechnological production and applications of glycolipid biosurfactants. Appl. Microbiol. Biotechnol. 2016, 100, 10265-10293. [CrossRef]

2. Varvaresou, A.; Iakovou, K. Biosurfactants in cosmetics and biopharmaceuticals. Lett. Appl. Microbiol. 2015, 61, 214-223. [CrossRef]

3. Jahan, R.; Bodratti, A.M.; Tsianou, M.; Alexandridis, P. Biosurfactants, natural alternatives to synthetic surfactants: Physicochemical properties and applications. Adv. Colloid Interface Sci. 2019, 275, 102061. [CrossRef] [PubMed]

4. Cortes-Sanchez Ade, J.; Hernandez-Sanchez, H.; Jaramillo-Flores, M.E. Biological activity of glycolipids produced by microorganisms: New trends and possible therapeutic alternatives. Microbiol. Res. 2013, 168, 22-32. [CrossRef]

5. Shekhar, S.; Sundaramanickam, A.; Balasubramanian, T. Biosurfactant producing microbes and their potential applications: A review. Crit. Rev. Environ. Sci. Technol. 2014, 45, 1522-1554. [CrossRef]

6. Chen, J.; Wu, Q.; Hua, Y.; Chen, J.; Zhang, H.; Wang, H. Potential applications of biosurfactant rhamnolipids in agriculture and biomedicine. Appl. Microbiol. Biotechnol. 2017, 101, 8309-8319. [CrossRef]

7. Chen, W.C.; Juang, R.S.; Wei, Y.H. Applications of a lipopeptide biosurfactant, surfactin, produced by microorganisms. Biochem. Eng. J. 2015, 103, 158-169. [CrossRef]

8. McClements, D.J.; Gumus, C.E. Natural emulsifiers-Biosurfactants, phospholipids, biopolymers, and colloidal particles: Molecular and physicochemical basis of functional performance. Adv. Colloid Interface Sci. 2016, 234, 3-26. [CrossRef] [PubMed]

9. Ramani, K.; Jain, S.C.; Mandal, A.B.; Sekaran, G. Microbial induced lipoprotein biosurfactant from slaughterhouse lipid waste and its application to the removal of metal ions from aqueous solution. Colloids Surf. B Biointerfaces 2012, 97, 254-263. [CrossRef]

10. Mnif, I.; Ellouz-Chaabouni, S.; Ghribi, D. Glycolipid biosurfactants, main classes, functional properties and related potential applications in environmental biotechnology. J. Polym. Environ. 2017, 26, 2192-2206. [CrossRef]

11. Rahimi, K.; Lotfabad, T.B.; Jabeen, F.; Mohammad Ganji, S. Cytotoxic effects of mono- and di-rhamnolipids from Pseudomonas aeruginosa MR01 on MCF-7 human breast cancer cells. Colloids Surfaces B Biointerfaces 2019, 181, 943-952. [CrossRef] 
12. Hardin, R.; Pierre, J.; Schulze, R.; Mueller, C.M.; Fu, S.L.; Wallner, S.R.; Stanek, A.; Shah, V.; Gross, R.A.; Weedon, J.; et al. Sophorolipids improve sepsis survival: Effects of dosing and derivatives. J. Surg. Res. 2007, 142, 314-319. [CrossRef]

13. Banat, I.M.; De Rienzo, M.A.; Quinn, G.A. Microbial biofilms: Biosurfactants as antibiofilm agents. Appl. Microbiol. Biotechnol. 2014, 98, 9915-9929. [CrossRef] [PubMed]

14. Borsanyiova, M.; Patil, A.; Mukherji, R.; Prabhune, A.; Bopegamage, S. Biological activity of sophorolipids and their possible use as antiviral agents. Folia Microbiol. 2016, 61, 85-89. [CrossRef] [PubMed]

15. Mnif, I.; Ghribi, D. Glycolipid biosurfactants: Main properties and potential applications in agriculture and food industry. J. Sci. Food Agric. 2016, 96, 4310-4320. [CrossRef]

16. Jimoh, A.A.; Lin, J. Biosurfactant: A new frontier for greener technology and environmental sustainability. Ecotoxicol. Environ. Saf. 2019, 184, 109607. [CrossRef] [PubMed]

17. Eslami, P.; Hajfarajollah, H.; Bazsefidpar, S. Recent advancements in the production of rhamnolipid biosurfactants by Pseudomonas aeruginosa. RSC Adv. 2020, 10, 34014-34032. [CrossRef]

18. Bergstrom, S.; Theorell, H.; Davide, H. On a metabolic product of ps pyocyanea, pyolipic acid, active against mycobact tuberculosis. Arkiv Kemi Mineral. Och Geologi 1947, 23, 1-12.

19. Bergstrom, S.; Theorell, H.; Davide, H. Pyolipic acid, a metabolic product of Pseudomonas pyocyanea, active against Mycobacterium tuberculosis. Arch. Biochem. 1946, 10, 165-166.

20. Jarvis, F.G.; Johnson, M.J. A glyco-lipide produced by Pseudomonas aeruginosa. J. Am. Chem. Soc. 1949, 71, 4124-4126. [CrossRef]

21. Edwards, J.R.; Hayashi, J.A. Structure of a rhamnolipid from Pseudomonas aeruginosa. Arch. Biochem. Biophys. 1965, 111, 415-421. [CrossRef]

22. Geys, R.; Soetaert, W.; Van Bogaert, I. Biotechnological opportunities in biosurfactant production. Curr. Opin Biotechnol. 2014, 30, 66-72. [CrossRef]

23. Dubeau, D.; Deziel, E.; Woods, D.E.; Lepine, F. Burkholderia thailandensis harbors two identical rhl gene clusters responsible for the biosynthesis of rhamnolipids. BMC Microbiol. 2009, 9, 263. [CrossRef]

24. Andrä, J.; Rademann, J.; Howe, J.; Koch, M.H.J.; Heine, H.; Zähringer, U.; Brandenburg, K. Endotoxin-like properties of a rhamnolipid exotoxin from Burkholderia (Pseudomonas) plantarii: Immune cell stimulation and biophysical characterization. Biol. Chem. 2006, 387, 301-310. [CrossRef]

25. Howe, J.; Bauer, J.; Andra, J.; Schromm, A.B.; Ernst, M.; Rossle, M.; Zahringer, U.; Rademann, J.; Brandenburg, K. Biophysical characterization of synthetic rhamnolipids. FEBS J. 2006, 273, 5101-5112. [CrossRef]

26. Itoh, S.H.; Tomita, F.; Suzuki, T. Rhamnolipids produced by Pseudomonas aeruginosa grown on n-paraffin (mixture of C $12, \mathrm{C} 13$ and C 14 fractions). J. Antibiot. 1971, 24, 855-859. [CrossRef]

27. Ceresa, C.; Tessarolo, F.; Maniglio, D.; Tambone, E.; Carmagnola, I.; Fedeli, E.; Caola, I.; Nollo, G.; Chiono, V.; Allegrone, G.; et al. Medical-grade silicone coated with rhamnolipid R89 is effective against Staphylococcus spp. biofilms. Molecules 2019, $24,3843$. [CrossRef]

28. De Freitas Ferreira, J.; Vieira, E.A.; Nitschke, M. The antibacterial activity of rhamnolipid biosurfactant is pH dependent. Food Res. Int. 2019, 116, 737-744. [CrossRef] [PubMed]

29. Sanchez, M.; Teruel, J.A.; Espuny, M.J.; Marques, A.; Aranda, F.J.; Manresa, A.; Ortiz, A. Modulation of the physical properties of dielaidoylphosphatidylethanolamine membranes by a dirhamnolipid biosurfactant produced by Pseudomonas aeruginosa. Chem. Phys. Lipids 2006, 142, 118-127. [CrossRef]

30. Araujo, L.V.D.; Guimarães, C.R.; Marquita, R.L.D.S.; Santiago, V.M.J.; De Souza, M.P.; Nitschke, M.; Freire, D.M.G. Rhamnolipid and surfactin: Anti-adhesion/antibiofilm and antimicrobial effects. Food Control. 2016, 63, 171-178. [CrossRef]

31. Abdollahi, S.; Tofighi, Z.; Babaee, T.; Shamsi, M.; Rahimzadeh, G.; Rezvanifar, H.; Saeidi, E.; Mohajeri Amiri, M.; Saffari Ashtiani, Y.; Samadi, N. Evaluation of anti-oxidant and anti-biofilm activities of biogenic surfactants derived from Bacillus amyloliquefaciens and Pseudomonas aeruginosa. Iran J. Pharm. Res. 2020, 19, 115-126.

32. Elshikh, M.; Funston, S.; Chebbi, A.; Ahmed, S.; Marchant, R.; Banat, I.M. Rhamnolipids from non-pathogenic Burkholderia thailandensis E264: Physicochemical characterization, antimicrobial and antibiofilm efficacy against oral hygiene related pathogens. New Biotechnol. 2017, 36, 26-36. [CrossRef]

33. Kim, L.H.; Jung, Y.; Yu, H.W.; Chae, K.J.; Kim, I.S. Physicochemical interactions between rhamnolipids and Pseudomonas aeruginosa biofilm layers. Environ. Sci. Technol. 2015, 49, 3718-3726. [CrossRef]

34. Kim, B.S.; Lee, J.Y.; Hwang, B.K. In vivo control and in vitro antifungal activity of rhamnolipid B, a glycolipid antibiotic, against Phytophthora capsici and Colletotrichum orbiculare. Pest. Manag. Sci. 2000, 56, 1029-1035. [CrossRef]

35. Goswami, D.; Borah, S.N.; Lahkar, J.; Handique, P.J.; Deka, S. Antifungal properties of rhamnolipid produced by Pseudomonas aeruginosa DS9 against Colletotrichum falcatum. J. Basic Microbiol. 2015, 55, 1265-1274. [CrossRef]

36. Sen, S.; Borah, S.N.; Kandimalla, R.; Bora, A.; Deka, S. Efficacy of a rhamnolipid biosurfactant to inhibit Trichophyton rubrum in vitro and in a mice model of dermatophytosis. Exp. Dermatol. 2019, 28, 601-608. [CrossRef] [PubMed]

37. Singh, N.; Pemmaraju, S.C.; Pruthi, P.A.; Cameotra, S.S.; Pruthi, V. Candida biofilm disrupting ability of di-rhamnolipid (RL-2) produced from Pseudomonas aeruginosa DSVP20. Appl. Biochem. Biotechnol. 2013, 169, 2374-2391. [CrossRef] [PubMed]

38. Devendra, H.; Dusane, S.D. Yarlagadda V Nancharaiah, Ameeta Ravi Kumar, Vayalam P. Venugopalan and Smita S Zinjarde*, Disruption of Yarrowia lipolytica biofilms by rhamnolipid biosurfactant. Aquat. Biosyst. 2012, 8, 1-7. 
39. Rodrigues, L.R.; Banat, I.M.; Van der Mei, H.C.; Teixeira, J.A.; Oliveira, R. Interference in adhesion of bacteria and yeasts isolated from explanted voice prostheses to silicone rubber by rhamnolipid biosurfactants. J. Appl. Microbiol. 2006, 100, 470-480. [CrossRef]

40. Sotirova, A.V.; Spasova, D.I.; Galabova, D.N.; Karpenko, E.; Shulga, A. Rhamnolipid-biosurfactant permeabilizing effects on gram-positive and gram-negative bacterial strains. Curr. Microbiol. 2008, 56, 639-644. [CrossRef]

41. Sotirova, A.; Avramova, T.; Stoitsova, S.; Lazarkevich, I.; Lubenets, V.; Karpenko, E.; Galabova, D. The importance of rhamnolipidbiosurfactant-induced changes in bacterial membrane lipids of Bacillus subtilis for the antimicrobial activity of thiosulfonates. Curr. Microbiol. 2012, 65, 534-541. [CrossRef]

42. Chen, X.; Li, P.; Shen, Y.; Zou, Y.; Yuan, G.; Hu, H. Rhamnolipid-involved antibiotics combinations improve the eradication of Helicobacter pylori biofilm in vitro: A comparison with conventional triple therapy. Microb. Pathog. 2019, 131, 112-119. [CrossRef]

43. Jezierska, S.; Claus, S.; Van Bogaert, I. Yeast glycolipid biosurfactants. FEBS Lett. 2018, 592, 1312-1329. [CrossRef]

44. Gorin, P.A.J.; Spencer, J.F.T.; Tulloch, A.P. Hydroxy Fatty acid glycosides of sophorose from Torulopsis magnoliae. Can. J. Chem. 1961, 39, 846-855. [CrossRef]

45. Tulloch, A.P.; Spencer, J.F.T.; Deinema, M.H. A new hydroxy fatty acid sophoroside from Candida bogoriensis. Can. J. Chem. 1968, 46, 345-348. [CrossRef]

46. Kurtzman, C.P.; Price, N.P.J.; Ray, K.J.; Kuo, T.-M. Production of sophorolipid biosurfactants by multiple species of the Starmerella (Candida) bombicola yeast clade. FEMS Microbiol. Lett. 2010, 311, 140-146. [CrossRef] [PubMed]

47. Park, T.H.G.M.; Lee, J.; Chen, J.; Song, X.; Zhang, H.; Qu, Y. Production, structure elucidation and anticancer properties of sophorolipid from Wickerhamiella domercqiae. Enzyme Microb. Technol. 2006, 39, 501-506.

48. Van Bogaert, I.N.; Saerens, K.; De Muynck, C.; Develter, D.; Soetaert, W.; Vandamme, E.J. Microbial production and application of sophorolipids. Appl. Microbiol. Biotechnol. 2007, 76, 23-34. [CrossRef]

49. Shin, J.D.; Lee, J.; Kim, Y.B.; Han, I.-S.; Kim, E.-K. Production and characterization of methyl ester sophorolipids with 22-carbonfatty acids. Bioresour. Technol. 2010, 101, 3170-3174. [CrossRef] [PubMed]

50. Van Bogaert, I.N.A.; Zhang, J.; Soetaert, W. Microbial synthesis of sophorolipids. Process Biochem. 2011, 46, 821-833. [CrossRef]

51. Ankulkar, R.; Chavan, M. Characterisation and application studies of sophorolipid biosurfactant by Candida tropicalis RA1. J. Pure Appl. Microbiol. 2019, 13, 1653-1665. [CrossRef]

52. Fontoura, I.C.C.D.; Saikawa, G.I.A.; Silveira, V.A.I.; Pan, N.C.; Amador, I.R.; Baldo, C.; Rocha, S.P.D.D.; Celligoi, M.A.P.C Antibacterial activity of sophorolipids from Candida bombicola against human pathogens. Braz. Arch. Biol. Technol. 2020, 63, e20180568. [CrossRef]

53. Gaur, V.K.; Regar, R.K.; Dhiman, N.; Gautam, K.; Srivastava, J.K.; Patnaik, S.; Kamthan, M.; Manickam, N. Biosynthesis and characterization of sophorolipid biosurfactant by Candida spp.: Application as food emulsifier and antibacterial agent. Bioresour. Technol. 2019, 285, 121314. [CrossRef] [PubMed]

54. Solaiman, D.K.Y.; Ashby, R.D.; Uknalis, J. Characterization of growth inhibition of oral bacteria by sophorolipid using a microplate-format assay. J. Microbiol. Methods 2017, 136, 21-29. [CrossRef] [PubMed]

55. Silveira, V.A.I.; Nishio, E.K.; Freitas, C.A.U.Q.; Amador, I.R.; Kobayashi, R.K.T.; Caretta, T.; Macedo, F.; Celligoi, M.A.P.C. Production and antimicrobial activity of sophorolipid against Clostridium perfringens and Campylobacter jejuni and their additive interaction with lactic acid. Biocatal. Agric. Biotechnol. 2019, 21, 101287. [CrossRef]

56. Ceresa, C.; Fracchia, L.; Williams, M.; Banat, I.M.; Díaz De Rienzo, M.A. The effect of sophorolipids against microbial biofilms on medical-grade silicone. J. Biotechnol. 2020, 309, 34-43. [CrossRef] [PubMed]

57. Sen, S.; Borah, S.N.; Bora, A.; Deka, S. Production, characterization, and antifungal activity of a biosurfactant produced by Rhodotorula babjevae YS3. Microb. Cell Factories 2017, 16, 1-14. [CrossRef]

58. Haque, F.; Alfatah, M.; Ganesan, K.; Bhattacharyya, M.S. Inhibitory effect of sophorolipid on Candida albicans biofilm formation and hyphal growth. Sci. Rep. 2016, 6, 1-11. [CrossRef]

59. Haque, F.; Verma, N.K.; Alfatah, M.; Bijlani, S.; Bhattacharyya, M.S. Sophorolipid exhibits antifungal activity by ROS mediated endoplasmic reticulum stress and mitochondrial dysfunction pathways in Candida albicans. RSC Adv. 2019, 9, 41639-41648. [CrossRef]

60. Chen, J.; Liu, X.; Fu, S.; An, Z.; Feng, Y.; Wang, R.; Ji, P. Effects of sophorolipids on fungal and oomycete pathogens in relation to pH solubility. J. Appl. Microbiol. 2020, 128, 1754-1763. [CrossRef]

61. Zhang, X.; Fan, X.; Solaiman, D.K.Y.; Ashby, R.D.; Liu, Z.; Mukhopadhyay, S.; Yan, R. Inactivation of Escherichia coli O157:H7 in vitro and on the surface of spinach leaves by biobased antimicrobial surfactants. Food Control 2016, 60, 158-165. [CrossRef]

62. Sen, S.; Borah, S.N.; Kandimalla, R.; Bora, A.; Deka, S. Sophorolipid biosurfactant can control cutaneous dermatophytosis caused by Trichophyton mentagrophytes. Front Microbiol. 2020, 11, 329. [CrossRef]

63. Arutchelvi, J.I.; Bhaduri, S.; Uppara, P.V.; Doble, M. Mannosylerythritol lipids: A review. J. Ind. Microbiol. Biotechnol. 2008, 35, 1559-1570. [CrossRef] [PubMed]

64. Haskins, R.H.; Thorn, J.A.; Boothroyd, B. Biochemistry of the ustilaginales: XI. metabolic products of Ustilago zeae in submerged culture. Can. J. Microbiol. 1955, 1, 749-756. [CrossRef] [PubMed]

65. Morita, T.; Koike, H.; Koyama, Y.; Hagiwara, H.; Ito, E.; Fukuoka, T.; Imura, T.; Machida, M.; Kitamoto, D. Genome Sequence of the Basidiomycetous yeast Pseudozyma antarctica T-34, a producer of the glycolipid biosurfactants mannosylerythritol lipids. Genome Announc. 2013, 1, e0006413. [CrossRef] 
66. Saika, A.; Koike, H.; Fukuoka, T.; Yamamoto, S.; Kishimoto, T.; Morita, T. A Gene cluster for biosynthesis of mannosylerythritol lipids consisted of 4-O-beta-D-Mannopyranosyl-(2R,3S)-Erythritol as the sugar moiety in a Basidiomycetous yeast Pseudozyma tsukubaensis. PLoS ONE 2016, 11, e0157858. [CrossRef] [PubMed]

67. Konishi, M.; Hatada, Y.; Horiuchi, J. Draft genome sequence of the Basidiomycetous yeast-like fungus Pseudozyma hubeiensis SY62, which produces an abundant amount of the biosurfactant mannosylerythritol lipids. Genome Announc. 2013, 1. [CrossRef]

68. Saika, A.; Koike, H.; Fukuoka, T.; Morita, T. Tailor-made mannosylerythritol lipids: Current state and perspectives. Appl. Microbiol. Biotechnol. 2018, 102, 6877-6884. [CrossRef]

69. Kitamoto, D.; Yanagishita, H.; Endo, A.; Nakaiwa, M.; Nakane, T.; Akiya, T. Remarkable antiagglomeration effect of a yeast biosurfactant, diacylmannosylerythritol, on ice-water slurry for cold thermal storage. Biotechnol. Prog. 2001, 17, $362-365$. [CrossRef]

70. Morita, T.; Fukuoka, T.; Imura, T.; Kitamoto, D. Mannosylerythritol lipids: Production and applications. J. Oleo Sci. 2015, 64, 133-141. [CrossRef]

71. Kitamoto, D. Surface active properties and antimicrobial activities of mannosylerythritol lipids as biosurfactants produced by Candida antarctica. Sci. World J. 1993, 29, 91-96. [CrossRef]

72. Fukuoka, T.; Morita, T.; Konishi, M.; Imura, T.; Sakai, H.; Kitamoto, D. Structural characterization and surface-active properties of a new glycolipid biosurfactant, mono-acylated mannosylerythritol lipid, produced from glucose by Pseudozyma antarctica. Appl. Microbiol. Biotechnol. 2007, 76, 801-810. [CrossRef] [PubMed]

73. Recke, V.K.; Beyrle, C.; Gerlitzki, M.; Hausmann, R.; Syldatk, C.; Wray, V.; Tokuda, H.; Suzuki, N.; Lang, S. Lipase-catalyzed acylation of microbial mannosylerythritol lipids (biosurfactants) and their characterization. Carbohydr. Res. 2013, 373, 82-88. [CrossRef] [PubMed]

74. Okuhira, K.; Koike, S.; Ito, S.; Kobayashi, Y. The bio-surfactant mannosylerythritol lipid acts as a selective antibacterial agent to modulate rumen fermentation. Anim. Sci. J. 2020, 91, e13464. [CrossRef]

75. Nashida, J.; Nishi, N.; Takahashi, Y.; Hayashi, C.; Igarashi, M.; Takahashi, D.; Toshima, K. Systematic and stereoselective total synthesis of mannosylerythritol lipids and evaluation of their antibacterial activity. J. Org. Chem. 2018, 83, 7281-7289. [CrossRef] [PubMed]

76. Shu, Q.; Niu, Y.; Zhao, W.; Chen, Q. Antibacterial activity of mannosylerythritol lipids against vegetative cells and spores of Bacillus cereus. Food Control 2019, 106, 106711. [CrossRef]

77. Shu, Q.; Wei, T.; Lu, H.; Niu, Y.; Chen, Q. Mannosylerythritol lipids: Dual inhibitory modes against Staphylococcus aureus through membrane-mediated apoptosis and biofilm disruption. Appl. Microbiol. Biotechnol. 2020, 104, 5053-5064. [CrossRef] [PubMed]

78. Liu, X.; Shu, Q.; Chen, Q.; Pang, X.; Wu, Y.; Zhou, W.; Wu, Y.; Niu, J.; Zhang, X. Antibacterial efficacy and mechanism of mannosylerythritol lipids-A on Listeria monocytogenes. Molecules 2020, 25, 4857. [CrossRef]

79. Yoshida, S.; Koitabashi, M.; Nakamura, J.; Fukuoka, T.; Sakai, H.; Abe, M.; Kitamoto, D.; Kitamoto, H. Effects of biosurfactants, mannosylerythritol lipids, on the hydrophobicity of solid surfaces and infection behaviours of plant pathogenic fungi. J. Appl. Microbiol. 2015, 119, 215-224. [CrossRef]

80. Merghni, A.; Dallel, I.; Noumi, E.; Kadmi, Y.; Hentati, H.; Tobji, S.; Ben Amor, A.; Mastouri, M. Antioxidant and antiproliferative potential of biosurfactants isolated from Lactobacillus casei and their anti-biofilm effect in oral Staphylococcus aureus strains. Microb. Pathog. 2017, 104, 84-89. [CrossRef]

81. Haskins, R.H.; Thorn, J.A. Biochemistry of the ustilaginales: VII. antibiotic activity of ustilagic acid. Can. J. Botany 1951, 29, 585-592. [CrossRef]

82. Spoeckner, S.; Wray, V.; Nimtz, M.; Lang, S. Glycolipids of the smut fungus Ustilago maydis from cultivation on renewable resources. Appl. Microbiol. Biotechnol. 1999, 51, 33-39. [CrossRef]

83. Kulakovskaya, E.V.; Kulakovskaya, T.V.; Golubev, V.I.; Shashkov, A.S.; Grachev, A.A.; Nifantiev, N.E. Fungicidal activity of cellobiose lipids from culture broth of yeast Cryptococcus humicola and Pseudozyma fusiformata. Russ. J. Bioorganic Chem. 2007, 33, 156-160. [CrossRef]

84. Golubev, W.I.; Kulakovskaya, T.V.; Shashkov, A.S.; Kulakovskaya, E.V.; Golubev, N.V. Antifungal cellobiose lipid secreted by the epiphytic yeast Pseudozyma graminicola. Microbiology 2008, 77, 171-175. [CrossRef]

85. Mimee, B.; Labbe, C.; Belanger, R.R. Catabolism of flocculosin, an antimicrobial metabolite produced by Pseudozyma flocculosa. Glycobiology 2009, 19, 995-1001. [CrossRef] [PubMed]

86. Oraby, A.; Werner, N.; Sungur, Z.; Zibek, S. Factors affecting the synthesis of cellobiose lipids by Sporisorium scitamineum. Front. Bioeng. Biotechnol. 2020, 8, 555647. [CrossRef]

87. Ludmila, V.; Trilisenko, E.V.K.; Kulakovskaya, T.V.; Yu Ivanov, A.; Penkov, N.V.; Vagabov, V.M.; Kulaev, I.S. The antifungal effect of cellobiose lipid on the cells of Saccharomyces cerevisiae depends on carbon source. Springerplus 2012, 1, 1-6.

88. Puchkov, E.O.; Zähringer, U.; Lindner, B.; Kulakovskaya, T.V.; Seydel, U.; Wiese, A. Mycocidal, membrane-active complex of Cryptococcus humicola is a new type of cellobiose lipid with detergent features. Biochim. Biophys. Acta 2002, 1558, 161-170. [CrossRef]

89. Kulakovskaya, E.V.; Ivanov, A.Y.; Kulakovskaya, T.V.; Vagabov, V.M.; Kulaev, I.S. Effects of cellobiose lipid B on Saccharomyces cerevisiae cells: $\mathrm{K}+$ leakage and inhibition of polyphosphate accumulation. Microbiology 2008, 77, 288-292. [CrossRef]

90. Mimee, B.; Labbe, C.; Pelletier, R.; Belanger, R.R. Antifungal activity of flocculosin, a novel glycolipid isolated from Pseudozyma flocculosa. Antimicrob. Agents Chemother. 2005, 49, 1597-1599. [CrossRef] 
91. Mimee, B.; Pelletier, R.; Belanger, R.R. In vitro antibacterial activity and antifungal mode of action of flocculosin, a membraneactive cellobiose lipid. J. Appl. Microbiol. 2009, 107, 989-996. [CrossRef] [PubMed]

92. Guo, Z.; Chen, Y.; Wang, Y.; Jiang, H.; Wang, X. Advances and challenges in metallic nanomaterial synthesis and antibacterial applications. J. Mater. Chem. B 2020, 8, 4764-4777. [CrossRef] [PubMed]

93. Yousefi, M.; Ehsani, A.; Jafari, S.M. Lipid-based nano delivery of antimicrobials to control food-borne bacteria. Adv. Colloid Interface Sci. 2019, 270, 263-277. [CrossRef]

94. Kasture, M.B.; Patel, P.; Prabhune, A.A.; Ramana, C.V.; Kulkarni, A.A.; Prasad, B.L.V. Synthesis of silver nanoparticles by sophorolipids: Effect of temperature and sophorolipid structure on the size of particles. J. Chem. Sci. 2008, 120, 515-520. [CrossRef]

95. Xin, Q.; Shah, H.; Nawaz, A.; Xie, W.; Akram, M.Z.; Batool, A.; Tian, L.; Jan, S.U.; Boddula, R.; Guo, B.; et al. Antibacterial carbon-based nanomaterials. Adv. Mater. 2019, 31, e1804838. [CrossRef]

96. Basak, G.; Das, D.; Das, N. Dual role of acidic diacetate sophorolipid as biostabilizer for ZnO nanoparticle synthesis and biofunctionalizing agent against Salmonella enterica and Candida albicans. J. Microbiol. Biotechnol. 2014, 24, 87-96. [CrossRef]

97. Khalid, H.F.; Tehseen, B.; Sarwar, Y.; Hussain, S.Z.; Khan, W.S.; Raza, Z.A.; Bajwa, S.Z.; Kanaras, A.G.; Hussain, I.; Rehman, A. Biosurfactant coated silver and iron oxide nanoparticles with enhanced anti-biofilm and anti-adhesive properties. J. Hazard Mater. 2019, 364, 441-448. [CrossRef]

98. Das, M.; Patowary, K.; Vidya, R.; Malipeddi, H. Microemulsion synthesis of silver nanoparticles using biosurfactant extracted from Pseudomonas aeruginosa MKVIT3 strain and comparison of their antimicrobial and cytotoxic activities. IET Nanobiotechnol. 2016, 10, 411-418. [CrossRef]

99. Joanna, C.; Marcin, L.; Ewa, K.; Grazyna, P. A nonspecific synergistic effect of biogenic silver nanoparticles and biosurfactant towards environmental bacteria and fungi. Ecotoxicology 2018, 27, 352-359. [CrossRef] [PubMed]

100. Bidyarani, N.; Srivastav, A.K.; Gupta, S.K.; Kumar, U. Synthesis and physicochemical characterization of rhamnolipid-stabilized carvacrol-loaded zein nanoparticles for antimicrobial application supported by molecular docking. J. Nanoparticle Res. 2020, 22, 1-13. [CrossRef]

101. Marangon, C.A.; Martins, V.C.A.; Ling, M.H.; Melo, C.C.; Plepis, A.M.G.; Meyer, R.L.; Nitschke, M. Combination of rhamnolipid and chitosan in nanoparticles boosts their antimicrobial efficacy. ACS Appl. Mater. Interfaces 2020, 12, 5488-5499. [CrossRef]

102. Shikha, S.; Chaudhuri, S.R.; Bhattacharyya, M.S. Facile one pot greener synthesis of sophorolipid capped gold nanoparticles and its antimicrobial activity having special efficacy against gram negative Vibrio cholerae. Sci. Rep. 2020, 10, 1463. [CrossRef] [PubMed]

103. Wu, J.; Shu, Q.; Niu, Y.; Jiao, Y.; Chen, Q. Preparation, characterization, and antibacterial effects of chitosan nanoparticles embedded with essential oils synthesized in an Ionic liquid containing system. J. Agric. Food Chem. 2018, 66, 7006-7014. [CrossRef]

104. Bakur, A.; Niu, Y.; Kuang, H.; Chen, Q. Synthesis of gold nanoparticles derived from mannosylerythritol lipid and evaluation of their bioactivities. AMB Express 2019, 9, 62. [CrossRef]

105. Vasudevan, S.; Prabhune, A.A. Photophysical studies on curcumin-sophorolipid nanostructures: Applications in quorum quenching and imaging. R. Soc. Open Sci. 2018, 5, 170865. [CrossRef] [PubMed]

106. Bakur, A.; Elshaarani, T.; Niu, Y.; Chen, Q. Comparative study of antidiabetic, bactericidal, and antitumor activities of MEL@AgNPs, MEL@ZnONPs, and Ag-ZnO/MEL/GA nanocomposites prepared by using MEL and gum arabic. RSC Adv. 2019, 9, 9745-9754. [CrossRef]

107. Filipczak, N.; Pan, J.; Yalamarty, S.S.K.; Torchilin, V.P. Recent advancements in liposome technology. Adv. Drug Deliv. Rev. 2020, 156, 4-22. [CrossRef]

108. Barenholz, Y. Doxil(R)-the first FDA-approved nano-drug: Lessons learned. J. Controll. Release Off. J. Controlled Release Soc. 2012, 160, 117-134. [CrossRef] [PubMed]

109. Manca, M.L.; Sinico, C.; Maccioni, A.M.; Diez, O.; Fadda, A.M.; Manconi, M. Composition influence on pulmonary delivery of rifampicin liposomes. Pharmaceutics 2012, 4, 590-606. [CrossRef]

110. Manca, M.L.; Valenti, D.; Sales, O.D.; Nacher, A.; Fadda, A.M.; Manconi, M. Fabrication of polyelectrolyte multilayered vesicles as inhalable dry powder for lung administration of rifampicin. Int. J. Pharm. 2014, 472, 102-109. [CrossRef]

111. Melis, V.; Manca, M.L.; Bullita, E.; Tamburini, E.; Castangia, I.; Cardia, M.C.; Valenti, D.; Fadda, A.M.; Peris, J.E.; Manconi, M.; et al. Inhalable polymer-glycerosomes as safe and effective carriers for rifampicin delivery to the lungs. Coll. Surf. B Biointerfaces 2016, 143, 301-308. [CrossRef]

112. Fan, L.; Xie, P.; Wang, Y.; Liu, X.; Li, Y.; Zhou, J. Influences of mannosylerythritol lipid-A on the self-assembling structure formation and functional properties of heat-induced $\beta$-lactoglobulin aggregates. Food Hydrocoll. 2019, 96, 310-321. [CrossRef]

113. Wu, J.; Niu, Y.; Jiao, Y.; Chen, Q. Fungal chitosan from Agaricus bisporus (Lange) Sing. Chaidam increased the stability and antioxidant activity of liposomes modified with biosurfactants and loading betulinic acid. Int. J. Biol. Macromol. 2019, 123, 291-299. [CrossRef]

114. Fan, L.; Chen, Q.; Mairiyangu, Y.; Wang, Y.; Liu, X. Stable vesicle self-assembled from phospholipid and mannosylerythritol lipid and its application in encapsulating anthocyanins. Food Chem. 2020, 344, 128649. [CrossRef]

115. Haque, F.; Sajid, M.; Cameotra, S.S.; Battacharyya, M.S. Anti-biofilm activity of a sophorolipid-amphotericin B niosomal formulation against Candida albicans. Biofouling 2017, 33, 768-779. [CrossRef] [PubMed] 
116. Ter Beek, J.; Guskov, A.; Slotboom, D.J. Structural diversity of ABC transporters. J. Gen. Physiol. 2014, 143, 419-435. [CrossRef] [PubMed]

117. Kim, S.Y.; Park, C.; Jang, H.J.; Kim, B.; Bae, H.W.; Chung, I.Y.; Kim, E.S.; Cho, Y.H. Antibacterial strategies inspired by the oxidative stress and response networks. J. Microbiol. 2019, 57, 203-212. [CrossRef] [PubMed]

118. Surekha, K.; Satputea, A.G.B.; Ibrahim, M.; Banatb, J.N.; Sangshettic, R.H.P.; Gaded, A.W.N. Multiple roles of biosurfactants in biofilms. Curr. Pharm. Des. 2016, 22, 1429-1448.

119. Juma, A.; Lemoine, P.; Simpson, A.B.J.; Murray, J.; O’Hagan, B.M.G.; Naughton, P.J.; Dooley, J.G.; Banat, I.M. Microscopic investigation of the combined use of antibiotics and biosurfactants on methicillin resistant Staphylococcus aureus. Front. Microbiol. 2020, 11, 1477. [CrossRef]

120. Joshi-Navare, K.; Prabhune, A. A biosurfactant-sophorolipid acts in synergy with antibiotics to enhance their efficiency. Biomed. Res. Int. 2013, 2013, 512495. [CrossRef] [PubMed] 